
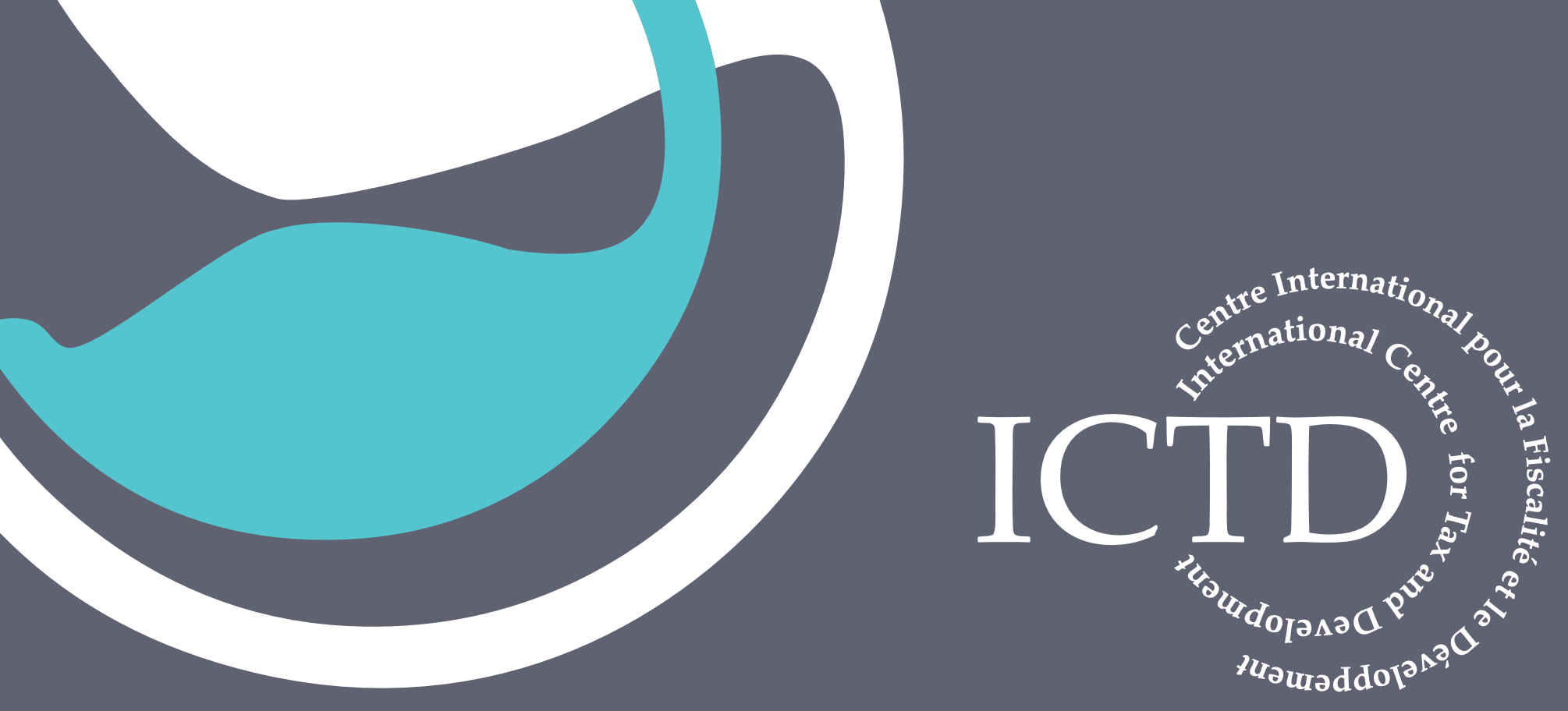

Working Paper 68

\title{
How Do We Measure Tax Expenditures? The Zambian Example
}

Miljan Sladoje

October 2017 


\section{ICTD Working Paper 68}

\section{How Do We Measure Tax Expenditures? The Zambian Example}

Miljan Sladoje

October 2017 
How Do We Measure Tax Expenditures? The Zambian Example Miljan Sladoje

ICTD Working Paper 68

First published by the Institute of Development Studies in October 2017

(C) Institute of Development Studies 2017

ISBN: 978-1-78118-383-0

\section{(c) $(1)(9$}

This is an Open Access paper distributed under the terms of the Creative Commons Attribution Non Commercial 4.0 International license, which permits downloading and sharing provided the original authors and source are credited - but the work is not used for commercial purposes. http://creativecommons.org/licenses/by-nc/4.0/legalcode

Available from:

The International Centre for Tax and Development at the Institute of Development Studies, Brighton BN1 9RE, UK

Tel: +44 (0) 1273606261

Email: info@ictd.ac.uk

Web: www.ictd/en/publications

IDS is a charitable company limited by guarantee and registered in England

Charity Registration Number 306371

Charitable Company Number 877338 


\section{How Do We Measure Tax Expenditures? The Zambian Example}

Miljan Sladoje

\section{Summary}

The objective of this paper is to help inform future tax reforms related to tax expenditure provisions in Zambia. It sets out how tax expenditures can be categorised, measured and evaluated, and provides guidance on establishing a robust framework for monitoring and evaluating tax expenditures in Zambia.

Keywords: tax expenditures; Zambia; tax incentives; revenue forgone; revenue mobilisation; tax policy; tax reform; tax administration.

Miljan Sladoje is a Country Economist for the International Growth Centre in Zambia. He was previously an Overseas Development Institute Fellow at the Zambia Revenue Authority. He holds an MSc in Economics from the University of Copenhagen, and an MSc in Development Economics from the School of Oriental and African Studies. 


\section{Contents}

Summary 3

Acronyms $\quad 6$

$\begin{array}{ll}\text { Introduction } & 7\end{array}$

$1 \quad$ Tax expenditures as a public policy tool 8

1.1 Definition of tax expenditures 8

$\begin{array}{lll}1.2 & \text { Broad categories of tax expenditures } & 9\end{array}$

$\begin{array}{lll}1.3 & \text { Measuring the impact of tax expenditures on tax revenue } & 10\end{array}$

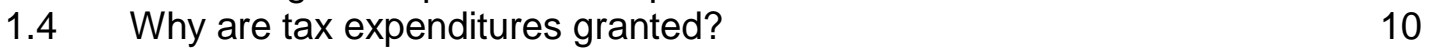

$\begin{array}{lll}1.5 & \text { Risks of tax expenditures } & 11\end{array}$

1.5.1 Revenue impact 11

1.5.2 Fiscal policy 12

1.6 Ensuring accountability and transparency of tax expenditures 13

1.6.1 Evaluation of tax expenditures 13

1.6.2 Integrating tax expenditures into the national budget process 14

$2 \quad$ Tax system in Zambia 14

$\begin{array}{ll}2.1 & 15\end{array}$

$\begin{array}{lll}2.2 & \text { Budgetary process } & 15\end{array}$

$\begin{array}{lll}2.3 & \text { Legal framework } & 15\end{array}$

3 Benchmark tax system and tax expenditures 16

$\begin{array}{lll}3.1 & \text { Benchmark tax system } & 17\end{array}$

3.1.1 Customs taxes 17

3.1.2 Domestic taxes - corporate income tax 18

$\begin{array}{lll}3.2 & \text { Tax expenditure identification } & 20\end{array}$

3.2.1 Customs taxes 20

3.2.2 Corporate income tax 23

$4 \quad$ Tax expenditure evaluation 26

$\begin{array}{lll}4.1 & \text { General characteristics of tax expenditures } & 27\end{array}$

4.1.1 Prevalence of discretionary measures 27

4.1.2 Lack of sunset provisions $\quad 27$

4.1.3 Lack of a clear policy rationale 27

4.1.4 Heavy administrative burden on the tax authority 28

4.2 ZDA tax incentives 29

4.2.1 Ambiguity and frequent changes in legal framework 30

4.2.2 Alignment to general policy framework 31

4.2.3 Promoting compliance requires better design of tax expenditures 31

4.2.4 Lack of coordination and enforcement capacity across government agencies 32

$5 \quad$ Reporting and evaluation of tax expenditure in Zambia 33

$6 \quad$ Summary of findings and recommendations 35

$\begin{array}{ll}\text { References } & 37\end{array}$ 
Tables

Table 1

Tax categories and types of taxes in Zambia, 2016

15

Table 2

Customs taxes in Zambia, 2016

Table 3

Domestic taxes in Zambia, 2016

18

Table 4

Customs tax expenditures in Zambia

21

Table 5

Corporate income tax rates, tax expenditures in Zambia, 2016

23

Loss carry-forward, tax expenditures in Zambia, 2016

24

Table 7

Corporate capital allowances, tax expenditures in Zambia, 2016

25

Table 8 ZDA tax provisions, 2016

Boxes

Box 1 Evaluation of tax expenditures

Box 2 Defining a benchmark tax system for capital depreciation

Box 3 ZDA - general priority sectors, 2016

Box 4 Estimates of impact on revenue in Zambia

Box 5 Monitoring and evaluation of tax expenditure - cross-country examples 


\section{Acronyms}

FDI Foreign direct investment

MCTI Ministry of Commerce, Trade and Industry

MFEZ Multi-facility economic zone

MoF Ministry of Finance

NGO Non-governmental organisation

SI Statutory Instrument

VAT Value Added Tax

ZDA Zambia Development Agency

ZRA Zambia Revenue Authority 


\section{Introduction}

This paper was motivated by increasing awareness of the importance of domestic resource mobilisation among the public, civil society organisations and policymakers in Zambia. Various forms of tax benefits often given to investors, commonly described as tax incentives, have received much attention. These are perceived to result in a significant loss in tax revenue for the Government of Zambia, and have been subject to increasing scrutiny in recent reports (Fumpa-Makano and Imakondo 2015; MoFNP 2014b; Munyadi et al. 2012; Tuomi 2012).

While the government has taken steps in the past to rationalise tax incentive provisions, there is currently no effective mechanism in place to continuously assess their impact on revenue or their effectiveness in meeting public policy objectives. The objective of this paper is to help fill this gap. It aims to inform future research and policy initiatives in this area by setting out how tax expenditures in Zambia can be categorised, measured and evaluated, and to provide guidance on establishing a robust framework for monitoring and evaluating tax expenditures in Zambia. This paper does not estimate the impact of tax expenditure provisions on revenue - such an analysis would only influence policy decisions if the framework for monitoring and evaluating tax expenditures was integrated into the government's administrative and budget framework.

This paper adopts a slightly wider analytical framework than existing work on tax incentives on Zambia. It recognises that the Government of Zambia employs tax incentives to achieve a variety of policy objectives - social, environmental, political and economic - not just to attract investment. This broader category of tax provisions is called tax expenditures.

More specifically, the contribution of this paper can be categorised into four areas:

1. To offer a general discussion on the potential risks and benefits of tax expenditures, and identify best practice for improving reporting and evaluating tax expenditures in Zambia.

The premise of this paper is that tax expenditures can serve as useful policy tools, but also have the potential to undermine and distort a country's domestic resource mobilisation and fiscal policy. Tax expenditures can only be efficient and effective policy tools when coupled with:

- A solid informational basis for policy decisions on tax expenditures derived from a comprehensive system for reporting and evaluating tax expenditures; and

- Prudent and effective tax expenditure policy controls integrated into the national budgeting process.

2. To identify a benchmark tax system and provide partial overview of the range of tax expenditure provisions under the current tax system in Zambia.

Defining an overall benchmarking framework is a very large undertaking. Therefore the current paper illustrates the scope to apply this approach through a narrower focus on customs-related taxes and corporate income tax (excluding PAYE, domestic Value Added Tax (VAT), presumptive tax, mineral royalty and property transfer tax).

3. To examine the existing legal framework for tax expenditures, and the capacity for enforcement and coordination of the government agencies involved, in order to identify particular risk areas that deserve further scrutiny by policymakers and researchers. 
Evaluation of the legal framework for tax expenditure provisions suggests a need to redesign the tax expenditure framework in Zambia to improve general policy relevance, effectiveness in meeting policy objectives, and efficiency compared to alternative policy tools.

The analysis also suggests a need to strengthen the process for granting and administering tax incentives, and to improve coordination between the Zambia Development Agency (ZDA), Zambia Revenue Authority (ZRA), Ministry of Commerce, Trade and Industry (MCTI) and Ministry of Finance (MoF).

4. To outline how international best practice can be adapted to establish a system for reporting and evaluating tax expenditure in Zambia.

The paper argues that reporting and evaluation of tax expenditure should be incorporated into the national budgeting process to the extent permitted by existing institutional capacity. Initially a simplified approach could be adopted, introducing budgetary ceilings on tax expenditures. Subsequently, depending on the impact of the reform, more targeted evaluation and control measures can be considered. This would promote accountability, and create a solid information basis for policy decisions on tax expenditure in Zambia.

In this process it is important to recognise that appropriate management of tax expenditures requires the government agencies involved to coordinate and have enforcement capacity.

This paper also offers some insights that could be useful for studying tax expenditures in other African countries. Parallels can be drawn between Zambia and other countries in the region in terms of: the administrative framework for taxation; current tax structure; challenges related to broadening the tax base and the high degree of informality; extent of cross-country economic integration; structure of the economy; types and degree of proliferation of tax expenditures; and increasing awareness of the need to tackle fiscal challenges related to tax expenditures.

The rest of the paper is structured as follows. The first section provides definitions and the main concepts related to tax expenditures. It discusses the potential risks and benefits of tax expenditures, and international best practice for monitoring and evaluation of tax expenditures. Section 2 provides a brief overview of the tax system in Zambia, and the associated legal framework and budgetary processes. The following section identifies a benchmark tax system, and provides a partial overview of the range of tax expenditure provisions in Zambia as of 2016. Section 4 analyses the existing legal framework for tax expenditure provisions in Zambia, the role of various government agencies, and identifies particular risk areas for further analysis by policymakers and researchers. Section 5 considers how a tax expenditure and reporting system could be established and incorporated into the national budget process in Zambia. The final section provides a summary of findings and policy recommendations.

\section{Tax expenditures as a public policy tool}

This section provides definitions and the main concepts relating to tax expenditures, and discusses the pros and cons of employing tax expenditures to achieve public policy objectives.

\subsection{Definition of tax expenditures}

Policymakers can employ a country's tax system to meet public policy objectives in two distinct ways: 
- Direct fiscal expenditures: raising tax revenue and allocating funds directly to particular activities, businesses or government entities.

- Tax expenditures: tax breaks/reductions and the like granted to certain activities as incentives to promote certain behaviour (CRC Sogema 2013).

Hence, tax expenditures can sometimes provide an alternative to direct expenditures for meeting government objectives, and can have an effect on government finances. This explains the term tax expenditures - they are government expenditures, delivered through the tax system.

There is some disagreement on the exact definition of tax expenditures in literature and in practice. The current study will employ the definition of tax expenditures adopted by the Organisation for Economic Co-operation and Development (OECD 2010: 14), which highlights two central characteristics:

1. A tax expenditure is a tax provision that deviates from a benchmark tax system.

2. A tax expenditure is a tax provision that reduces the tax liability of the taxpayer, which impacts on government tax collection.

Thus, identifying and estimating the value of tax expenditures requires establishing a benchmark tax system - establishing relevant benchmark tax rates and tax bases for personal income, business income and consumption.

For instance, Zambian companies in the agricultural sector are taxed at a reduced rate of 10 per cent rather than the generally applicable/benchmark rate of 35 per cent, qualifying this provision as a tax expenditure. Similarly, the general VAT rate is 16 per cent, but certain categories of goods are zero-rated or exempt. In this case, the benchmark tax rate would be 16 per cent.

While the examples given above are relatively straightforward, in practice there is an aspect of judgement involved in establishing the benchmark tax system and identifying tax expenditures. The tax laws of countries differ significantly in various aspects, and therefore cross-country definitions of tax expenditures also vary (OECD 2010: 18).

\subsection{Broad categories of tax expenditures}

The most common categories of tax expenditures according to OECD are listed below (OECD 2010):

- Tax exemptions: incomes, goods and services that are excluded from the tax base. These can also be sector/individual specific (e.g. for non-governmental organisations (NGOs))

- Tax deductions/allowances: a deduction from gross income that arises due to various types of expenses incurred by the taxpayer. These can take the form of deductions for expenditures made to earn an investment income, or deductions for depreciation of assets.

- Tax deferrals: instances where a taxpayer can defer paying taxes on a certain amount of income to a future year. A common example are contributions to pension plans, where the contributions are tax-free but withdrawals in a future period are taxed. Other examples include deferment of payment of import VAT and mineral royalties. ${ }^{1}$

The benefits of tax deferrals on pensions are twofold. First, they allow for tax-free growth of the investment. Second, if the taxpayer falls into a lower income tax bracket in the future, the gains may be taxed at a lower rate. Import VAT deferrals are aimed at tackling cash-flow problems that arise for companies due to a delay between payment of import VAT and subsequent refund of import VAT. 
- Tax rate reductions: reductions in the tax rate for certain goods, sectors or individuals below the normally applicable rate.

- Tax credits: sums deducted from the tax liability to reduce the total tax payable. Unlike tax deductions that reduce taxable income, tax credits reduce the tax payable.

\subsection{Measuring the impact of tax expenditures on tax revenue}

There are three methods for estimating the value of the revenue loss attributable to tax expenditures, and each can be applied on a cash or accrual basis:

a) Revenue forgone: the revenue forgone method is an ex-post calculation of the amount of revenue lost relative to the benchmark tax due to tax expenditures, excluding any behavioural responses by taxpayers or impact on other tax types.

b) The outlay equivalence method: the outlay equivalence method is similar to revenue forgone, but in order to make tax expenditures more directly comparable to regular expenditures it adjusts for any potential differences in the tax liabilities associated with the two expenditure categories. In other words, it is an estimate of the direct expenditure that would be required to achieve the same after-tax benefit as a tax expenditure. For instance, if certain types of fiscal outlays are subject to income tax (whereas the equivalent tax expenditure is not), the tax that is typically levied would need to be added to the tax expenditure estimates.

c) Revenue gain: the revenue gain method is an ex-ante calculation of the amount of revenue to be gained from repealing the tax expenditure and reverting to the benchmark tax. This method also includes the impact of behavioural responses by taxpayers and the impact of the removal of a particular tax expenditure on revenue from other tax types.

In practice, most countries that compile reports on the impact of tax expenditures on revenue employ the revenue forgone method, due to its simplicity compared to the alternatives (Brixi et al. 2004). ${ }^{2}$

While estimating the impact on revenue is beyond the scope of this paper, the revenue forgone method would be the natural first step in estimating the revenue impact of tax expenditures in Zambia. Only partial estimates of the revenue impact of tax expenditure provisions in Zambia have been made in the past, and more advanced methods would be difficult to implement with the data currently available.

\subsection{Why are tax expenditures granted?}

Empirical studies indicate a growing proliferation of tax expenditures in the past few years, especially in developing countries (Abbas et al. 2012). While tax expenditures are utilised by governments to achieve a variety of public policy goals, one often-cited reason is attracting investment, primarily foreign direct investment (FDI).

From a social welfare perspective, the fundamental underlying justification for granting any type of tax expenditures should be that the benefits to society exceed the opportunity cost of the tax expenditure. The opportunity cost can be measured in terms of alternative forms of incentives, direct fiscal expenditures, or translating the additional revenue of repealing the tax expenditure into lower overall tax rates in the country.

\footnotetext{
The results of the revenue forgone method should be interpreted with caution due to a number of caveats: differences in tax systems and benchmark tax systems preclude cross-country comparisons of revenue forgone; estimates using the revenue forgone method are not necessarily additive, as tax expenditures are evaluated on an individual basis and do not account for the effects of the removal of one tax provision on the utilisation of other tax provisions (Australian Treasury 2014); comparisons of value and trends in tax expenditures over time can only be made assuming that the benchmark tax system used in the calculations is the same for all years (CRC Sogema 2013); behavioural responses by taxpayers in terms of economic activity are not modelled when applying this method.
} 
In essence, this requires an assessment of the effectiveness and efficiency of tax expenditures as public policy tools. One should be able to find an explanation for the proliferation of tax expenditures by answering two questions:

1. Are tax expenditures effective tools in meeting a specific public policy objective?

2. Are tax expenditures more efficient instruments compared to direct expenditures? ${ }^{3}$

In practice, though, this depth of analysis is usually lacking in decisions on tax policy. For instance, the common argument in support of tax expenditure provisions aimed at incentivising investment is that they lead to higher economic growth. This argument is often presented without any explanation of the underlying assumptions and economic theory. Moreover, surveys of investor perceptions, both in Zambia and other countries, indicate that investment incentives are not among the most important determinants of investment decisions. $^{4}$

Dean (2012) offers an alternative (and perhaps complementary) approach to explain the allure of tax expenditures to policymakers by using a 'fiscal advantages framework'. The framework is based on the premise that tax expenditures offer policymakers an opportunity to neutralise impediments to spending.

In this framework, tax expenditures are characterised as 'fiscal superconductors'. Just as electric superconductors reduce resistance to electricity flows, fiscal superconductors reduce impediments to spending. The advantages of tax expenditures come in three forms: budgetary, cognitive and procedural. Budgetary advantages are derived from the fact that tax expenditures are not included in the ordinary budget process. Cognitive advantages are similar to budgetary advantages, but focus on the psychological advantage of tax expenditures. Voters and policymakers may not recognise or accept the equivalence of tax expenditures and direct expenditures, even if tax expenditure reporting is part of the national budget. Lastly, procedural advantages arise when policymakers are able to avoid certain procedural obstacles in relation to the legislative process by substituting direct expenditures with tax expenditure provisions.

Overall, this analysis suggests that the proliferation of tax expenditures is a political phenomenon as well as an economic/accounting phenomenon.

\subsection{Risks of tax expenditures}

Extensive use of tax expenditures can undermine a country's tax revenue collection and general fiscal policy. The main areas of concern are outlined below.

\subsubsection{Revenue impact}

- Tax expenditures reduce tax revenue. They can have a negative impact on the overall budget balance if direct expenditure is not reduced accordingly. Poor administration and governance, and lack of transparency on tax expenditures, compound this effect.

- Depending on the design of the tax provision, tax expenditures can constitute openended funding - certain tax expenditures can expand with changes in society and the economy. In fact, the motivation behind tax expenditures can be to create incentives for

The latter question may seem puzzling, since we have established that tax expenditures and direct expenditures are in theory equivalent fiscal instruments. In practice, however, structural differences in bureaucracies may lead to different results from the two policy tools in terms of distribution of burdens and benefits for both government and beneficiaries.

A more detailed discussion of these issues is beyond the scope of this study. The following sources give an overview of some empirical results: Balance of Payments Statistical Committee (2015); MoFNP (2014); Tuomi (2012); Nathan-MSI Group (2004); Institute of Policy Analysis and Research Rwanda (2011); TJN Africa and ActionAid International (2012); Fjeldstad and Heggstad (2011). 
these shifts; without periodic review of these effects, tax expenditures can begin to jeopardise fiscal sustainability (Swift 2006).

- The use of tax incentives to attract investment can lead to tax competition between countries, leading to a 'race to the bottom'. Countries may continuously grant more tax incentives than their neighbours, thus eroding the tax base and resulting in a worse outcome for all countries involved (TJN Africa and ActionAid International 2012). ${ }^{5}$

- Tax expenditures add to the complexity of the tax system, making it more difficult to administer. Each tax expenditure programme is associated with a specific set of objectives and conditions that require a certain expertise to administer. This expertise is often lacking among tax administration officials, thus creating opportunities for abuse of tax expenditure provisions and creating more revenue loss (Swift 2006).

\subsubsection{Fiscal policy}

- Tax expenditures - like direct expenditures - can prove ineffective in meeting their stated policy objectives. A particular area that has been the subject of much debate is the effectiveness or ineffectiveness of tax expenditures in attracting investment.

- Tax expenditures affect priorities in resource allocation in the budgeting process and can negatively impact equality. Tax expenditures are, by definition, given a higher priority in resource allocation than direct fiscal outlays aimed at education, health and poverty reduction, because they are funded from the tax base (Swift 2006).

- Some empirical evidence indicates that tax incentives in many African countries are granted in favour of politically-connected individuals. This is both inefficient and compounds income inequality (TJN Africa and ActionAid International 2012).

- Tax expenditures tend to increase income inequality. Both income and consumption tax expenditures contribute to this inequality. Low-income earners often fall below the threshold to benefit from tax expenditures on income taxes, and tax expenditures on consumption taxes - even the ones aimed at essential goods - give larger absolute benefits to high-income earners (Swift 2006).

- Tax expenditures are not part of the annual budgetary review, and lack coordination with direct fiscal outlays and other tax expenditures. There are rarely any time limits associated with tax expenditures, and they are not evaluated against the original objectives behind their implementation. Consequently many tax expenditures overlap, are outdated in relation to their original purpose, and/or conflict with budget spending objectives (Swift 2006).

- Tax expenditures are often not subjected to the same scrutiny as fiscal outlays, with a lot of discretion, vague criteria and confidential agreements associated with granting tax expenditures (TJN Africa and ActionAid International 2012).

- Once implemented, tax expenditures can be politically difficult to repeal (although this applies to categories of direct expenditures as well). Tax expenditures may continue to

e.g. a study of tax incentives in SADC by the Nathan-MSI Group (2004) shows how Zambia had to resist political pressure to match a sharp tax cut implemented in Tanzania in 1992. In fact the tax cut proved to be disastrous for revenue collection in Tanzania. James (2003) gives an example of multinational companies shopping around for tax incentives - the Malaysian-based Rematex secured incredibly generous terms from the Namibian Government after also soliciting offers from South Africa, Madagascar and Botswana. 
erode the tax base even after they have been repealed, as the government can be pressurised into establishing provisions whereby tax expenditures remain in place for existing beneficiaries.

\subsection{Ensuring accountability and transparency of tax expenditures}

Because tax expenditures are government expenditures delivered through the tax system, they need be subject to evaluation and controls to determine how well they are meeting specific policy objectives, and whether they are associated with any unwanted outcomes.

\subsubsection{Evaluation of tax expenditures}

A three-step process is needed to promote accountability and transparency of policy decisions on tax expenditures.

1. Define a benchmark tax system and identify tax expenditure provisions.

2. Estimate the impact of tax expenditure provisions on revenue.

3. Evaluate the relevance, effectiveness and efficiency of tax expenditure provisions as public policy tools.

The first two steps can be described as 'tax expenditure reporting', the term coined to describe the process of defining a benchmark tax system, identifying tax expenditures and estimating their impact on revenue. The approach and methods involved have been discussed above. ${ }^{6}$ The last step requires tax expenditures to be evaluated as public policy tools.

While tax evaluation methods may vary across countries and across specific tax measures, it is nevertheless helpful to outline a general framework. Brixi et al. (2004) outline an approach for evaluating tax measures according to three key criteria: relevance, effectiveness and efficiency. A range of more specific questions can be considered under each of these criteria, as illustrated in Box 1:

\section{Box 1 Evaluation of tax expenditures}

\section{Relevance:}

- Is there a clear policy objective for the tax provision, and does the tax provision address an actual need? Is this policy objective consistent with the current socio-economic situation and the government's general policy direction?

- Are other policy instruments being used to achieve the same goal, and does the tax measure somehow complement this?

- Is the tax measure designed in a way that could reasonably be expected to influence economic behaviour/conditions for the targeted taxpayers? What are the conditions for accessing the tax expenditure?

- Is the duration of the tax measure in line with the policy objective? Does it include sunset provisions?

- What are the compliance and administration requirements associated with the tax measure?

Effectiveness:

- Is the tax measure meeting objectives within budget and without unwanted outcomes?

- Are the actual recipients aligned with the target population?

- $\quad$ Can changes in behaviour/conditions be attributed to the tax measure?

- How does the actual cost of the tax measure compare to the expected cost?

Efficiency:

- Is the tax measure the most efficient tool to achieve the relevant policy objective compared to alternative designs and policy options? (the specific methods used to answer this question depend to a very large extent on the policy objective in question.)

$6 \quad$ Many industrialised countries have adopted the general principles of tax expenditure analysis, and tax expenditure reporting has become a well-established practice in most OECD countries (IMF, OECD, UN and World Bank 2011; OECD International Database of Budget Practices). The Open Budget Survey 2012 by the International Budget Partnership shows that 41 out of 100 countries report at least some information on tax expenditures as part of the budgeting process. However, only 5 of the 25 countries surveyed in Sub-Saharan Africa (Burkina Faso, Ghana, Kenya, Tanzania and South Africa) provided information on tax expenditures as part of the budget process 
Discussion of the legal underpinnings of tax expenditure provisions in Zambia will draw on the above framework as much as possible. Since the current analysis does not estimate the revenue impact of tax expenditure provisions, the discussion will mostly focus on questions relating to the relevance of tax expenditure measures.

\subsubsection{Integrating tax expenditures into the national budget process}

Reporting and evaluation of tax expenditure needs to be integrated into the annual budget process in order to influence policy decisions. This helps to form a more complete national budget, ensuring that tax expenditures are subjected to the same budgetary controls as fiscal outlays. This also helps to mitigate the risks associated with tax expenditures by limiting the impact on revenue, ensuring better coordination of government resources, and promoting effective and efficient use of tax expenditure provisions.

However, this recommendation comes with two caveats. First, it is important to recognise that the evaluation and control of tax expenditures can only be as good as the overall budgetary process. Second, before adopting the recommendations it is important to consider the potential administrative burden arising from tax expenditure reporting and evaluation, and weigh this against the expected benefits. ${ }^{7}$

Indeed, developing countries may struggle to expand their existing budget process to ensure prudent analysis of both spending and non-spending programmes. In these instances, simplified tax expenditure budgeting approaches may be considered.

For instance, Brixi et al. (2004) suggest that a good second-best option to ease the administrative burden is to consider doing away with a rigorous tax expenditure evaluation, and instead implement budgetary ceilings on tax expenditure spending, similar to ceilings on government guarantees. ${ }^{8}$

More generally, the specific framework for incorporating tax expenditure evaluation can be adapted to the existing national budgeting process. It can thus provide a starting point for additional reforms, in conjunction with overall development of the process for national fiscal management.

\section{Tax system in Zambia}

Section 2 discusses the structure of the Zambian tax system. It also explains the process for formulating tax policies, and outlines the legal framework of the tax system.

\footnotetext{
Phillips (2012) analyses the risks associated with tax expenditure reporting with a particular focus on India, and identifies three key risk areas. First, the benefits of tax expenditure reporting are exaggerated, in terms of reducing revenue loss. Second, there is evidence that the burden of tax expenditure reporting may add to the administrative burden of already strained tax administrations. Third, the study argues that tax expenditure analysis may serve as a back door for tax policy that is unsuitable for a particular country, but advocated by international organisations. The same paper also argues that there is very little room in general to evaluate and discuss the supposed self-evident benefits of tax expenditure reporting and analysis. The issue has generally been framed within the context of good governance and transparency. Consequently, developing countries are unable to question the rationale of the prescriptions without losing credibility. Shaviro (2004) argues that tax expenditure reporting in the US has had little impact on the use of tax expenditures by policymakers. Dean (2012) also argues that the prevalent understanding of tax expenditure reporting has failed both as a constraint on policy-making behaviour and as an accounting tool to identify risk areas.

8 Designing effective commitment devices in relation to tax expenditures, such as a budgetary ceiling on tax expenditures, is difficult due to ambiguity in the definition of tax expenditures. Moreover, the enforcement of such devices is subject to the same political and institutional constraints that necessitate such a rule in the first place. See Dean (2012).
} 


\subsection{Tax categories in Zambia}

The tax system in Zambia can be segmented into three broad tax categories: income taxes, consumption taxes and trade taxes. The types of taxes falling under each of these categories are illustrated in Table 1:

Table 1 Tax categories and types of taxes in Zambia, 2016

\begin{tabular}{ll}
\hline \hline Tax category & Type of tax \\
\hline \multirow{2}{*}{ Income taxes } & $\begin{array}{l}\text { Company income tax } \\
\text { Pay As You Earn (PAYE) } \\
\text { Withholding tax } \\
\text { Mineral royalty }\end{array}$ \\
\hline Consumption taxes & Domestic and import Value Added Tax \\
& Domestic and import excise duty \\
\hline Trade taxes & Import duty \\
\hline \hline
\end{tabular}

Source: Customs and Excise Act, Volume 18, Cap 322 - Laws of Zambia;

Income Tax Act, Volume 19, Cap 323 - Laws of Zambia

The tax system also includes non-tax instruments, such as the fuel levy, rural electrification fund levy, carbon emission surtax and motor vehicle licensing fees.

\subsection{Budgetary process}

The ZRA is mandated to administer and collect tax revenue in Zambia, while local councils administer and collect fees, rates and levies. Tax policy formulation is conducted through the Tax Policy Review Committee (TPRC), which is formed by the Ministry of Finance (MoF), the lead institution in the process of tax policy formulation. TPRC is made up of experts on tax policy and administration from ZRA, MoF and other government departments. Nongovernment actors (including individuals, NGOs and business associations) can also submit tax proposals to the TPRC (Bwalya et al. 2009).

The proposals from committee members and non-government actors are assessed by the TPRC, which subsequently makes recommendations to the Minister of Finance. The proposed budget is presented to the Cabinet for further debate and approval; after this it is presented to parliament and subjected to a parliamentary debate. The budget is adopted and made into law through a parliamentary vote (Bwalya et al. 2009).

Although the ZRA has previously conducted partial analysis of tax expenditures, there is currently no regular and transparent mechanism integrated into the national budget process to assess the impact of tax expenditures.

\subsection{Legal framework}

The legal framework of taxation in Zambia consists of several categories of legal documents. These are Acts, Statutory Instruments (SIs), and administrative rules issued by the Commissioner General of the ZRA. ${ }^{9}$

\footnotetext{
The legal framework for customs and excise taxes consists of the following documents: The Customs and Excise Act; The Customs And Excise Regulations; Statutory Instruments; and Rules issued by Commissioner General of ZRA.

The legal framework for VAT including Import VAT consists of the following documents: Value Added Tax Act; Statutory Instruments; Rules issued by Commissioner General of ZRA.

The legal framework for income tax consists of the following documents: Income Tax Act; Statutory Instruments; Rules issued by Commissioner General of ZRA.
} 
The Acts (Customs and Excise Act, Income Tax Act and VAT Act) are the chief legal documents; they include enabling laws and regulations. Amendments to the Acts can only be implemented with parliamentary approval.

However, there are provisions granting the minister of finance power to remit, exempt or suspend the whole or any part of taxes and duties through issuance of Sls (Income Tax Act: Paragraph 15, Subsection 2; Customs and Excise Act, Section 89). In contrast, increases in tax rates cannot be implemented without parliamentary approval.

The SIs, on the other hand, need not be subjected to parliamentary approval and are not incorporated into the Acts. Moreover, there is no consolidated legal document including all the regulations and Sls for the different tax types.

Finally, the Acts also grant certain powers to the commissioner general of the ZRA to implement certain administrative rules. These, again, are not incorporated into the Acts.

As will be illustrated in the following sections, the legal framework of the Zambian tax system greatly complicates the task of compiling an exhaustive inventory of tax expenditures.

Beyond the domestic legal framework, it should be noted that Zambia has ratified investment protection treaties with China, Cuba, Egypt, Finland, France, Germany, Italy, Netherlands, United Kingdom and United States. These treaties can limit the scope for revisions to taxation of existing foreign investment - the rolling back of incentives could be interpreted as confiscation under these agreements, and could prompt international arbitration.

\section{Benchmark tax system and tax expenditures}

The objective of this section is to identify a benchmark tax system and associated tax expenditure provisions in Zambia as of 2016. Section 3.1 provides a detailed overview of the definitions and applicable rates of the tax types in Zambia, and identifies the benchmark tax system for the tax types included in the tax expenditure analysis. Section 3.2 discusses the tax expenditure provisions under the selected tax categories. The analysis is divided into customs taxes and domestic taxes according to the operational set-up of the ZRA.

Defining a benchmarking tax system and identifying tax expenditures is a very comprehensive undertaking. The tax expenditures analysis in subsequent sections illustrate the scope to apply this approach through a narrower focus on corporate income and customs taxes.

Our analysis does not include PAYE, mineral royalty, presumptive tax, property transfer tax, presumptive tax or domestic VAT. This may limit the scope to identify tax expenditures with overlapping policy objectives, but otherwise it does not impact the analysis or conclusions reached. The same would be true if one were to estimate revenue forgone based on a subsection of tax types, as revenue forgone estimates are strictly speaking not additive across tax types. Most tax expenditure reports tend to ignore this fact.

As discussed in Section 1, countries' tax laws differ significantly in various aspects, and therefore cross-country definitions of tax expenditures also vary. There is an aspect of judgement involved in establishing the benchmark tax system and identifying tax expenditures. The approach adopted here - outlined in Section 3.1 - is largely based on the operational definitions in use by the ZRA. This ensures that the definitions and any derived policy recommendations are appropriate for the country context, and have the greatest chance of influencing tax policy decisions. However, the disadvantage of this approach is 
that these definitions may not always be aligned to international best practice.

\subsection{Benchmark tax system}

\subsubsection{Customs taxes}

Table 2 provides a broad definition of the various types of customs taxes and generally applicable rates. The table also specifies the benchmark tax system that will be employed to identify tax expenditure provisions.

\section{Table 2 Customs taxes in Zambia, 2016}

\begin{tabular}{|c|c|c|c|}
\hline Tax type & Definition & Applicable rates & $\begin{array}{l}\text { Benchmark tax } \\
\text { system }\end{array}$ \\
\hline $\begin{array}{l}\text { Customs } \\
\text { duty }\end{array}$ & $\begin{array}{l}\text { Customs duty is a levy/tax charged on } \\
\text { the customs value (CIF) of imported } \\
\text { goods and administered as specified in } \\
\text { the Customs and Excise Act, Volume } \\
18 \text {, Cap, } 322 \text { - Laws of Zambia. }\end{array}$ & $\begin{array}{l}0-5 \% \text { on capital equipment and raw } \\
\text { materials } \\
15 \% \text { on intermediate goods } \\
25 \% \text { of finished goods } \\
\text { The specific customs duty rates for } \\
\text { each type of good is specified in the } \\
\text { First Schedule of the Customs and } \\
\text { Excise Act, Volume 18, Cap. } 322- \\
\text { Laws of Zambia, according to the } \\
\text { International Convention on the } \\
\text { Harmonised Commodity Description } \\
\text { and Coding System. }\end{array}$ & $\begin{array}{l}\text { The rates for customs } \\
\text { duty specified in the } \\
\text { Customs and Excise } \\
\text { Act and applying to } \\
2016 \text { will be adopted as } \\
\text { the benchmark tax } \\
\text { system. }\end{array}$ \\
\hline $\begin{array}{l}\text { Export } \\
\text { duty }\end{array}$ & $\begin{array}{l}\text { Export duty is a levy/tax charged on } \\
\text { the customs value of exported goods } \\
\text { and administered as specified in the } \\
\text { Customs and Excise Act, Volume } 18 \text {, } \\
\text { Cap, } 322 \text { - Laws of Zambia. The tax is } \\
\text { meant to encourage further processing } \\
\text { of locally produced goods. }\end{array}$ & $\begin{array}{l}\text { The standard tariff for export duty is } \\
10 \% \text { of the customs value. } \\
\text { The range of goods and products } \\
\text { subject to export duty and associated } \\
\text { rates are specified in the Ninth } \\
\text { Schedule of the Customs and Excise } \\
\text { Act, Volume 18, Cap. } 322 \text { - Laws of } \\
\text { Zambia. }\end{array}$ & $\begin{array}{l}\text { The rates for export } \\
\text { duty specified in the } \\
\text { Customs and Excise } \\
\text { Act and applying to } \\
2016, \text { will be adopted } \\
\text { as part of the } \\
\text { benchmark tax system. }\end{array}$ \\
\hline $\begin{array}{l}\text { Excise } \\
\text { duty } \\
\text { (local and } \\
\text { import) }\end{array}$ & $\begin{array}{l}\text { Excise is a tax on particular goods or } \\
\text { products or a range of particular goods } \\
\text { or products, whether produced } \\
\text { domestically or imported, and may be } \\
\text { imposed at any stage of production or } \\
\text { distribution by reference to the weight, } \\
\text { strength, or quantity of the goods or } \\
\text { products. Excise tax includes among } \\
\text { other, duty on cigarettes, alcohol, fuel } \\
\text { etc. }\end{array}$ & $\begin{array}{l}\text { Excise duty is charged on taxable } \\
\text { value i.e. customs value + customs } \\
\text { duty. } \\
\text { Petroleum products: K0.5-1.1 per litre } \\
\text { Motor vehicles: } 0-30 \% \\
\text { Tobacco products: } 145 \% \\
\text { Talk time: } 15 \% \\
\text { Wood: } 40 \% \\
\text { Charcoal: } 40 \% \\
\text { The range of goods and products } \\
\text { subject to excise duty and associated } \\
\text { rates are specified in the Second } \\
\text { Schedule of the Customs and Excise } \\
\text { Act, Volume } 18, \text { Cap. } 322-\text { Laws of } \\
\text { Zambia. }\end{array}$ & $\begin{array}{l}\text { The rates for customs } \\
\text { duty specified in the } \\
\text { Customs and Excise } \\
\text { Act and applying to } \\
2016 \text {, will be adopted } \\
\text { as part of the } \\
\text { benchmark tax system. }\end{array}$ \\
\hline $\begin{array}{l}\text { Motor } \\
\text { vehicle } \\
\text { licensing } \\
\text { fee }\end{array}$ & $\begin{array}{l}\text { Tax on motor vehicles permanently } \\
\text { imported into Zambia and covers } \\
\text { registration costs. }\end{array}$ & $\begin{array}{l}\text { Under the } 2016 \text { tax regime, the fee } \\
\text { was a lump sum amount of ZMW483 } \\
\text { per motor vehicle. }\end{array}$ & $\begin{array}{l}\text { The rate specified in the } \\
\text { Customs and Excise } \\
\text { Act will be adopted as } \\
\text { part of the benchmark } \\
\text { tax system. }\end{array}$ \\
\hline $\begin{array}{l}\text { Insurance } \\
\text { levy }\end{array}$ & $\begin{array}{l}\text { The Premium Levy Act No. } 21 \text { of } 2015 \\
\text { imposes a } 3 \% \text { levy on all insurance } \\
\text { premiums collected by insurers, } \\
\text { insurance agents and brokers. }\end{array}$ & $3 \%$ of premium value & - \\
\hline
\end{tabular}


Import VAT Tax on imported goods subject to VAT, charged on the taxable value i.e. customs value + customs duty (+ excise duty where applicable).

VAT-registered companies are eligible for claiming back Import VAT paid on imported inputs.

The compulsory registration threshold for VAT Registration is ZMW800,000.
The standard VAT rate of $16 \%$ is applied under import VAT. Some categories of goods and products are zero rated or exempt from import VAT.

The range of goods and products subject to standard import VAT, zerorated or exempt are specified in the

First Schedule of the Customs and Excise Act, Volume 18, Cap. 322 Laws of Zambia.
The rates for import VAT specified in the Customs and Excise

Act and applying to 2016, will be adopted as part of the benchmark tax system.

Source: The Customs and Excise Act, Volume 18, Cap 322 - Laws of Zambia; Value Added Tax Act, Volume 19, Cap 331 -

Laws of Zambia

The main legal provisions of the Zambia tax system in 2016 are adopted as the benchmark tax system - as specified in the Customs and Excise Act and Value Added Tax Act of 2016. Deviations from these regulations are interpreted as tax expenditures.

\subsubsection{Domestic taxes - corporate income tax}

Table 3 provides a broad definition of the taxes administered by the Domestic Taxes Division within the ZRA. Although, the table provides a definition of all domestic tax types, our analysis is limited to defining a benchmark tax system for corporate income tax using an income tax rate and associated provisions related to loss carry-forward and capital allowances.

Income as defined in the Income Tax Act includes: emoluments; annuities; dividends; interest, charges and discounts; royalties, premiums or any like consideration for the use or occupation of any property; income from the letting of property.

Table 3 Domestic taxes in Zambia, 2016

\begin{tabular}{|c|c|c|c|}
\hline Tax type & Definition & Applicable rates & Benchmark tax system \\
\hline Company tax & $\begin{array}{l}\text { Tax on profits of incorporated } \\
\text { businesses (companies with } \\
\text { turnover below ZMW } 800,000 \\
\text { can opt for the presumptive tax } \\
\text { regime) }\end{array}$ & $0-40 \%$ across different sectors & $\begin{array}{l}35 \% \\
5 \text {-year loss carry-forward } \\
\text { Straight line depreciation at the } \\
\text { specific rates applicable across } \\
5 \text { asset categories: Industrial, } \\
\text { commercial buildings, vehicles, } \\
\text { patents/trademarks. Capital } \\
\text { allowances for mining and } \\
\text { farming specific investments } \\
\text { which fall outside the above- } \\
\text { mentioned categories are also } \\
\text { included as part of the } \\
\text { benchmark tax system. } \\
\text { For dividends and interest } \\
\text { income, the benchmark tax rate } \\
\text { is set at } 15 \% \text {, in line with the } \\
\text { final tax under the withholding } \\
\text { tax regime. }\end{array}$ \\
\hline PAYE & $\begin{array}{l}\text { Tax on income from } \\
\text { employment }\end{array}$ & $\begin{array}{l}\text { Monthly income brackets: } \\
\text { ZMW0-3,000,000 - 0\% } \\
\text { ZMW3,000,000 - 3,800,000 - } 25 \% \\
\text { ZMW3,800,000 - 5,900,000 - 30\% } \\
\text { > ZMW5,900,000-35\% }\end{array}$ & 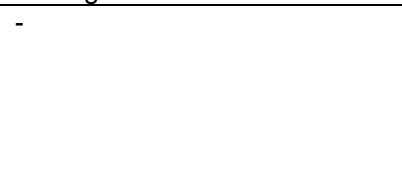 \\
\hline
\end{tabular}




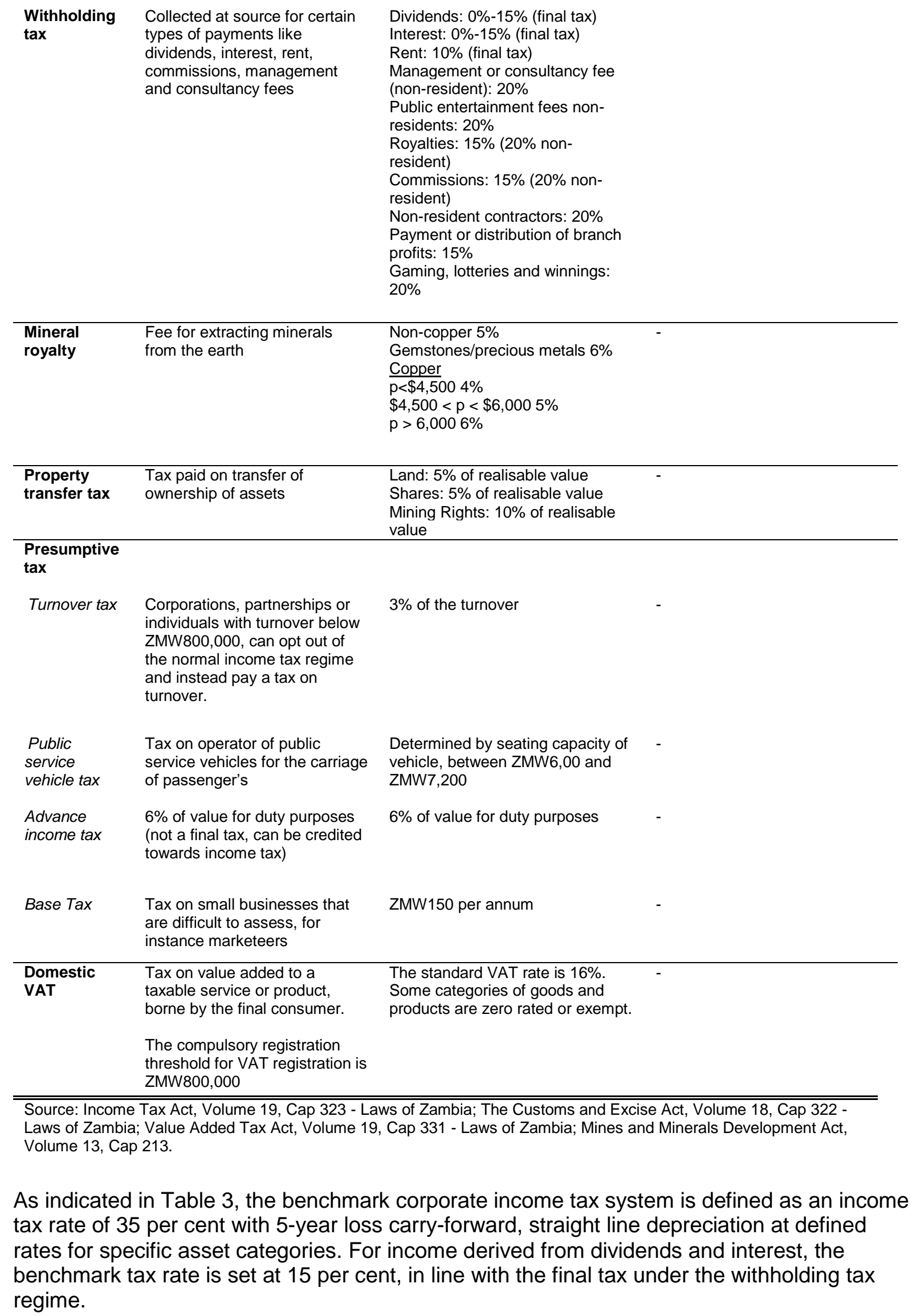

\begin{tabular}{lll}
\hline $\begin{array}{l}\text { Mineral } \\
\text { royalty }\end{array}$ & $\begin{array}{l}\text { Fee for extracting minerals } \\
\text { from the earth }\end{array}$ & $\begin{array}{l}\text { Non-copper } 5 \% \\
\text { Gemstones/precious metals 6\% } \\
\text { Copper }\end{array}$ \\
& & $\begin{array}{l}\text { p<\$4,500 } 4 \% \\
\$ 4,500<\mathrm{p}<\$ 6,0005 \% \\
\mathrm{p}>6,0006 \%\end{array}$ \\
& \\
\hline $\begin{array}{l}\text { Property } \\
\text { transfer tax }\end{array}$ & $\begin{array}{l}\text { Tax paid on transfer of } \\
\text { ownership of assets }\end{array}$ & $\begin{array}{l}\text { Land: } 5 \% \text { of realisable value } \\
\text { Shares: } 5 \% \text { of realisable value } \\
\text { Mining Rights: } 10 \% \text { of realisable } \\
\text { value }\end{array}$ \\
\hline
\end{tabular}

Public

service

vehicle tax

Tax on operator of public service vehicles for the carriage of passenger's

Advance income tax

$6 \%$ of value for duty purposes (not a final tax, can be credited towards income tax)

$\begin{array}{ll}\text { Base Tax } & \begin{array}{l}\text { Tax on small businesses that } \\ \text { are difficult to assess, for } \\ \text { instance marketeers }\end{array}\end{array}$

\begin{tabular}{lll}
\hline $\begin{array}{l}\text { Domestic } \\
\text { VAT }\end{array}$ & $\begin{array}{l}\text { Tax on value added to a } \\
\text { taxable service or product, } \\
\text { borne by the final consumer. }\end{array}$ & $\begin{array}{l}\text { The standard VAT rate is 16\%. } \\
\text { Some categories of goods and } \\
\text { products are zero rated or exempt. }\end{array}$ \\
& $\begin{array}{l}\text { The compulsory registration } \\
\text { threshold for VAT registration is } \\
\text { ZMW800,000 }\end{array}$ & \\
&
\end{tabular}

\section{$3 \%$ of the turnover}

Determined by seating capacity of vehicle, between ZMW6,00 and ZMW7,200

$6 \%$ of value for duty purposes

ZMW150 per annum

\author{
Some categories of goods and \\ products are zero rated or exempt.
}

\begin{abstract}
Source: Income Tax Act, Volume 19, Cap 323 - Laws of Zambia; The Customs and Excise Act, Volume 18, Cap 322 Laws of Zambia; Value Added Tax Act, Volume 19, Cap 331 - Laws of Zambia; Mines and Minerals Development Act, Volume 13, Cap 213.
\end{abstract}

As indicated in Table 3, the benchmark corporate income tax system is defined as an income tax rate of 35 per cent with 5-year loss carry-forward, straight line depreciation at defined rates for specific asset categories. For income derived from dividends and interest, the benchmark tax rate is set at 15 per cent, in line with the final tax under the withholding tax regime. 


\section{Box 2 Defining a benchmark tax system for capital depreciation}

While the process for defining a benchmark tax system is relatively straightforward for most tax types, the area of capital expenditures under company income taxes deserves a dedicated discussion. As a general rule, tax systems allow deductions for depreciation of assets, allowing capital to be written down in linear fashion over the economic life of an asset. For instance, an asset with an economic life of 5 years would be written down by $20 \%$ of the original purchase price over the course of the 5 years. In certain instances, categories of investors or capital are allowed depreciation at a higher rate than the true economic rate of depreciation (or the generally applicable rate). Excluding any behavioural responses and the effects of a progressive tax system, the effect of accelerated depreciation would be to delay tax payments. In practice, however, accelerated depreciation is usually also associated with lower tax payments over the whole depreciation period. Such provisions are therefore usually characterised as tax expenditures. Accordingly, the benchmark capital allowance would normally be defined as straight line depreciation over the economic life of an asset.

However, the regulations regarding depreciation and amortisation of capital in Zambia are fairly restrictive, with capital allowances specified as annual rates for defined asset categories. Therefore, we adopt a simplified approach and define the benchmark capital allowances as the specific annual rates applicable across 5 asset categories: industrial buildings, commercial buildings, plants/machinery, vehicles and patents/trademarks. Capital allowances for mining- and farmingspecific investments that fall outside the above-mentioned categories are also included as part of the benchmark tax system. Further details are provided in Table 7 below.

\subsection{Tax expenditure identification}

This section provides a detailed overview of the legal framework and policy base for each tax expenditure provision under customs and domestic taxes, respectively.

\subsubsection{Customs taxes}

The list or inventory of customs tax expenditures in Zambia in 2016 is based on data provided by the ZRA, and information derived from the relevant legal documents.

Table 4 lists the major categories of tax expenditures under customs taxes. Given the types of taxes falling under trade taxes, these tax expenditures qualify as either tax exemptions or tax reductions. The tax expenditures have been grouped into twenty-one categories: nineteen of these relate to customs duty; four relate to excise duty; one relates to export duty; and ten relate to import VAT. ${ }^{10}$

10 Certain categories of tax expenditures were excluded from the analysis as they were deemed to be part of the benchmark tax system. This includes: exemptions granted to diplomats and new residents; effects of deceased persons; exemptions on importation of modified vehicles for use by persons with disabilities; and exemptions on goods valued under US $\$ 1000$ for personal use. 
Table 4 Customs tax expenditures in Zambia, 2016

\begin{tabular}{|c|c|c|c|c|c|}
\hline & Tax provision & Policy objective & Legislation & Organisations & Goods \\
\hline $\begin{array}{l}\text { Southern } \\
\text { African } \\
\text { Development } \\
\text { Community } \\
\text { (SADC) }\end{array}$ & $\begin{array}{l}\text { Exemption from } \\
\text { customs duty on goods } \\
\text { originating in SADC } \\
\text { member states }\end{array}$ & $\begin{array}{l}\text { To promote inter- } \\
\text { regional trade and } \\
\text { development }\end{array}$ & $\begin{array}{l}\text { SADC trade } \\
\text { protocol incl. South } \\
\text { Africa }\end{array}$ & n.a. & $\begin{array}{l}\text { All goods originating in } \\
\text { SADC member states }\end{array}$ \\
\hline $\begin{array}{l}\text { Development } \\
\text { programmes }\end{array}$ & $\begin{array}{l}\text { Exemptions from } \\
\text { customs, excise and } \\
\text { import VAT for goods } \\
\text { imported for use in } \\
\text { development } \\
\text { programmes }\end{array}$ & $\begin{array}{l}\text { To promote } \\
\text { economic/social } \\
\text { development }\end{array}$ & $\begin{array}{l}\text { The Customs and } \\
\text { Excise Regulations } \\
\text { (SI } 54 \text { of 2000), } \\
\text { Part X, Regulation } \\
\text { 88. and 88B. }\end{array}$ & $\begin{array}{l}145 \\
\text { organisations } \\
\text { and government }\end{array}$ & All goods \\
\hline $\begin{array}{l}\text { Mining rights } \\
\text { holder }\end{array}$ & $\begin{array}{l}\text { Exemptions from } \\
\text { customs duty on mining } \\
\text { plant, mining machinery } \\
\text { or mining equipment }\end{array}$ & $\begin{array}{l}\text { Facilitating imports } \\
\text { of inputs into } \\
\text { mining operations }\end{array}$ & $\begin{array}{l}\text { The Customs and } \\
\text { Excise Regulations } \\
\text { (SI } 54 \text { of 2000), } \\
\text { Part X, Regulation } \\
96 \\
\text { Mining and } \\
\text { Minerals Act, } 2008\end{array}$ & $\begin{array}{l}\text { Mining rights } \\
\text { holders }\end{array}$ & $\begin{array}{l}\text { Mining plant, mining machinery } \\
\text { or mining equipment }\end{array}$ \\
\hline $\begin{array}{l}\text { Common } \\
\text { Market for } \\
\text { Eastern } \\
\text { and Southern } \\
\text { Africa } \\
\text { (COMESA) } \\
\end{array}$ & $\begin{array}{l}\text { Exemptions from } \\
\text { customs duty on goods } \\
\text { originating in COMESA } \\
\text { member states }\end{array}$ & $\begin{array}{l}\text { To promote inter- } \\
\text { regional trade and } \\
\text { development }\end{array}$ & $\begin{array}{l}\text { COMESA trade } \\
\text { protocol }\end{array}$ & n.a. & $\begin{array}{l}\text { All goods originating in } \\
\text { COMESA member states }\end{array}$ \\
\hline \multirow[t]{4}{*}{ Government } & $\begin{array}{l}\text { Exemption from } \\
\text { customs, excise, fuel } \\
\text { levy, MVF \& import } \\
\text { VAT on goods for GRZ }\end{array}$ & & & GRZ & Goods for use by GRZ \\
\hline & $\begin{array}{l}\text { Exemption from } \\
\text { customs, excise, fuel } \\
\text { levy, MVF and import } \\
\text { VAT on goods for } \\
\text { government agencies }\end{array}$ & & & $\begin{array}{l}\text { Government } \\
\text { agencies }\end{array}$ & $\begin{array}{l}\text { Goods for use by government } \\
\text { agencies }\end{array}$ \\
\hline & $\begin{array}{l}\text { Exemption from } \\
\text { customs, excise, fuel } \\
\text { levy, MVF and import } \\
\text { VAT on goods for } \\
\text { National Assembly }\end{array}$ & & $\begin{array}{l}\text { The Customs and } \\
\text { Excise } \\
\text { Regulations, } \\
\text { Regulation } 98\end{array}$ & National assembly & $\begin{array}{l}\text { Goods for use by members of } \\
\text { national assembly }\end{array}$ \\
\hline & $\begin{array}{l}\text { Exemption from excise } \\
\text { duty on goods } \\
\text { purchased in bond for } \\
\text { defence/armed forces }\end{array}$ & & $\begin{array}{l}\text { The Customs and } \\
\text { Excise } \\
\text { Regulations, } \\
\text { Regulation } 97\end{array}$ & $\begin{array}{l}10 \text { organisations } \\
\text { listed in 6th } \\
\text { schedule of } \\
\text { Customs and } \\
\text { Excise Regulations }\end{array}$ & $\begin{array}{l}\text { Beer, non-alcoholic beverages, } \\
\text { cigarettes, manufactured } \\
\text { tobacco, potable spirits }\end{array}$ \\
\hline $\begin{array}{l}\text { Zambia } \\
\text { Development } \\
\text { Agency (ZDA) }\end{array}$ & $\begin{array}{l}\text { Exemption from } \\
\text { customs duty on goods } \\
\text { for investments } \\
\text { approved by ZDA }\end{array}$ & $\begin{array}{l}\text { Investment } \\
\text { promotion }\end{array}$ & $\begin{array}{l}\text { The Customs and } \\
\text { Excise Regulations } \\
\text { (SI } 54 \text { of 2000), } \\
\text { Part X, Regulation } \\
\text { 98A,B,C,D. (excl. } \\
\text { 98D (d)) } \\
\text { ZDA Act No. } 11 \text { of } \\
2006\end{array}$ & $\begin{array}{l}289 \text { organisations } \\
\text { in total, businesses } \\
\text { engaged in priority } \\
\text { sectors, rural } \\
\text { enterprises, } \\
\text { manufacture of } \\
\text { motor vehicles, } \\
\text { trailers, motor } \\
\text { cycles, bicycles \& } \\
\text { roofing sheets. As } \\
\text { specified in The } \\
\text { Customs and } \\
\text { Excise Regulations } \\
\text { Fourth Schedule, } \\
\text { Part I }\end{array}$ & $\begin{array}{l}\text { Machinery and equipment } \\
\text { imported for use by the } \\
\text { approved organisations }\end{array}$ \\
\hline $\begin{array}{l}\text { Crude oil } \\
\text { suspension }\end{array}$ & $\begin{array}{l}\text { Exemption from } \\
\text { customs duty on crude } \\
\text { oil }\end{array}$ & $\begin{array}{l}\text { Ensuring supplies } \\
\text { of feedstock for } \\
\text { INDENI }\end{array}$ & Act 16 of 2013 & n.a. & Crude Oil HS2709 \\
\hline $\begin{array}{l}\text { Public benefit } \\
\text { organisations }\end{array}$ & $\begin{array}{l}\text { Exemption from } \\
\text { customs duty and } \\
\text { import VAT for public } \\
\text { benefit organisations }\end{array}$ & $\begin{array}{l}\text { Supporting } \\
\text { provision of goods } \\
\text { which government } \\
\text { is unable to } \\
\text { provide }\end{array}$ & $\begin{array}{l}\text { The Customs and } \\
\text { Excise Regulations } \\
\text { (SI54of 2000), } \\
\text { Regulation } 88 \mathrm{~A} \\
\text { SI } 7 \text { of } 2009 \\
\text { SI103 of } 2013\end{array}$ & $\begin{array}{l}\text { Public benefit } \\
\text { organisations as } \\
\text { defined in SI7 of } \\
2009\end{array}$ & $\begin{array}{l}\text { All goods and services for } \\
\text { provision of public benefits, excl. } \\
\text { cars, consumer electrical } \\
\text { appliances, household goods, } \\
\text { fire arms, beer, liquor, wine, } \\
\text { tobacco }\end{array}$ \\
\hline $\begin{array}{l}\text { Energy- } \\
\text { saving } \\
\text { equipment }\end{array}$ & $\begin{array}{l}\text { Exemptions from } \\
\text { customs duty and } \\
\text { import VAT on energy- } \\
\text { saving equipment }\end{array}$ & $\begin{array}{l}\text { Facilitating imports } \\
\text { of energy saving } \\
\text { equipment }\end{array}$ & $\begin{array}{l}\text { SI } 32 \text { and } 33 \text { of } \\
2008\end{array}$ & n.a. & $\begin{array}{l}\text { Solar batteries \& inverters, } \\
\text { energy efficient lamps, diesel } \\
\text { generators }\end{array}$ \\
\hline
\end{tabular}


Import VAT

exemptions/ zero-ratings
Exemption/zero-rating

from import VAT on

certain goods
VAT Act First

Schedule
As specified in VAT Liability

Guide.

Exempt: water supply services health services, educational services, booklets/newspapers, transportation services, conveyance sale \& lease of property, financial \& insurance services, funeral services, domestic kerosene, mosquito nets, food \& agriculture.

Zero-rated: supplies to privileged persons, building supplies fo public benefit organisations, medical supplies, educational materials, energy-saving appliances \& materials, agricultural equipment, food \& agriculture.

\begin{tabular}{|c|c|c|c|c|c|}
\hline $\begin{array}{l}\text { Multi-facility } \\
\text { Economic } \\
\text { Zones } \\
\text { (MFEZs) }\end{array}$ & $\begin{array}{l}\text { Exemption from } \\
\text { customs duty and } \\
\text { import VAT on goods } \\
\text { for use in the } \\
\text { development of MFEZs }\end{array}$ & $\begin{array}{l}\text { Promoting } \\
\text { development of } \\
\text { MFEZs }\end{array}$ & $\begin{array}{l}\text { The Customs and } \\
\text { Excise } \\
\text { Regulations, Part } \\
\text { X, Regulation 98D } \\
\text { (d) } \\
\text { SI } 172007\end{array}$ & $\begin{array}{l}5 \text { organisations } \\
\text { engaged in the } \\
\text { development of } \\
\text { MFEZs }\end{array}$ & $\begin{array}{l}\text { Machinery and equipment and } \\
\text { other goods specified in the bill } \\
\text { of quantities submitted with an } \\
\text { application for an approval } \\
\text { required for the development of } \\
\text { the MFEZ or an industrial park }\end{array}$ \\
\hline $\begin{array}{l}\text { Exemptions } \\
\text { approved by } \\
\text { minister }\end{array}$ & $\begin{array}{l}\text { Exemption from } \\
\text { customs duty on } \\
\text { manufacturing inputs } \\
\text { when duty rate is } \\
\text { higher than duty on } \\
\text { comparable finished } \\
\text { products }\end{array}$ & $\begin{array}{l}\text { Primarily aimed at } \\
\text { suspension of duty } \\
\text { on manufacturing } \\
\text { inputs aimed at } \\
\text { supporting the } \\
\text { manufacturing } \\
\text { industry }\end{array}$ & $\begin{array}{l}\text { The Customs and } \\
\text { Excise Act, Section } \\
89 \\
\text { S16 of } 2009\end{array}$ & $\begin{array}{l}\text { Manufacturing } \\
\text { companies }\end{array}$ & Inputs into manufacturing \\
\hline $\begin{array}{l}\text { Technical staff } \\
\text { of } \\
\text { development } \\
\text { programmes }\end{array}$ & $\begin{array}{l}\text { Exemptions from } \\
\text { customs \& excise duty } \\
\text { and import VAT on } \\
\text { goods for technical staff } \\
\text { of development } \\
\text { programmes }\end{array}$ & $\begin{array}{l}\text { Promoting } \\
\text { development }\end{array}$ & $\begin{array}{l}\text { The Customs and } \\
\text { Excise } \\
\text { Regulations, Part } \\
\text { X, Regulation } 90 \text {. }\end{array}$ & $\begin{array}{l}145 \text { approved } \\
\text { organisations }\end{array}$ & $\begin{array}{l}\text { Goods for technical staff of } \\
\text { approved development } \\
\text { programmes }\end{array}$ \\
\hline $\begin{array}{l}\text { Electronic } \\
\text { communication } \\
\text { regulation }\end{array}$ & $\begin{array}{l}\text { Exemption from } \\
\text { customs duty on certain } \\
\text { goods for organisations } \\
\text { engaged in } \\
\text { constructing electronic } \\
\text { communication towers }\end{array}$ & $\begin{array}{l}\text { Promoting } \\
\text { development of } \\
\text { electronic } \\
\text { communication } \\
\text { infrastructure }\end{array}$ & SI23 of 2011 & $\begin{array}{l}\text { Companies } \\
\text { engaged in } \\
\text { construction of } \\
\text { electronic } \\
\text { communication } \\
\text { towers }\end{array}$ & $\begin{array}{l}\text { Towers, structures, electronic } \\
\text { communication equipment, } \\
\text { computer equipment etc. }\end{array}$ \\
\hline $\begin{array}{l}\text { TAZARA, } \\
\text { Zambia River } \\
\text { Authority and } \\
\text { Oil Pipeline }\end{array}$ & $\begin{array}{l}\text { Exemption from } \\
\text { customs \& excise duty } \\
\text { on goods for use by } \\
\text { TAZARA, Zambia River } \\
\text { Authority and Oil } \\
\text { Pipeline }\end{array}$ & & $\begin{array}{l}\text { The Customs and } \\
\text { Excise Regulations } \\
\text { (SI } 54 \text { of 2000), } \\
\text { Part X, Regulation } \\
91,91 \mathrm{~A} \text { and } 92\end{array}$ & $\begin{array}{l}\text { TAZARA, Zambia } \\
\text { River Authority and } \\
\text { Oil Pipeline }\end{array}$ & \\
\hline $\begin{array}{l}\text { Aircraft stores } \\
\text { and } \\
\text { equipment }\end{array}$ & $\begin{array}{l}\text { Exemptions from } \\
\text { customs duty and } \\
\text { import VAT on aircraft } \\
\text { stores and equipment }\end{array}$ & $\begin{array}{l}\text { Promoting aviation } \\
\text { sector in Zambia }\end{array}$ & $\begin{array}{l}\text { The Customs and } \\
\text { Excise Regulations } \\
\text { (SI } 54 \text { of 2000), } \\
\text { Part X, Regulation } \\
94 \text { and } 95\end{array}$ & n.a. & Aircraft stores and equipment \\
\hline $\begin{array}{l}\text { Energy } \\
\text { Regulation } \\
\text { Board } \\
\text { licenced } \\
\text { companies }\end{array}$ & $\begin{array}{l}\text { Exemption from } \\
\text { customs duty on certain } \\
\text { types of petroleum } \\
\text { products }\end{array}$ & $\begin{array}{l}\text { Ensuring } \\
\text { availability of } \\
\text { petroleum products } \\
\text { not produced by } \\
\text { INDENI }\end{array}$ & Sl13 of 2003 & $\begin{array}{l}\text { Oil marketing } \\
\text { companies } \\
\text { licenced by the } \\
\text { Energy Regulation } \\
\text { Board }\end{array}$ & $\begin{array}{l}\text { Specific petroleum products as } \\
\text { specified in SI13 of } 20013\end{array}$ \\
\hline $\begin{array}{l}\text { Sporting } \\
\text { equipment* }\end{array}$ & $\begin{array}{l}\text { Exemption from } \\
\text { customs duty on } \\
\text { sporting equipment }\end{array}$ & & SI94 of 2012 & n.a. & $\begin{array}{l}\text { Headgear and articles or } \\
\text { equipment for general physical } \\
\text { exercise }\end{array}$ \\
\hline $\begin{array}{l}\text { Manganese } \\
\text { ores/ } \\
\text { concentrates }\end{array}$ & $\begin{array}{l}\text { Exemption from export } \\
\text { duty for manganese } \\
\text { ores/concentrates }\end{array}$ & & SI 15 of 2012 & n.a. & Manganese concentrates/ores \\
\hline $\begin{array}{l}\text { Public } \\
\text { transport } \\
\text { aircraft }\end{array}$ & $\begin{array}{l}\text { Exemption from } \\
\text { customs duty and } \\
\text { import VAT on fuel, } \\
\text { lubricants and other } \\
\text { consumable goods for } \\
\text { public transport aircraft }\end{array}$ & $\begin{array}{l}\text { Promoting aviation } \\
\text { sector in Zambia }\end{array}$ & $\begin{array}{l}\text { The Customs and } \\
\text { Excise Regulations } \\
\text { (SI } 54 \text { of 2000), } \\
\text { Part X, Regulation } \\
93\end{array}$ & n.a. & $\begin{array}{l}\text { Consumable technical supplies } \\
\text { for public transport aircraft }\end{array}$ \\
\hline $\begin{array}{l}\text { Medical/ } \\
\text { agricultural } \\
\text { equipment }\end{array}$ & $\begin{array}{l}\text { Exemption from } \\
\text { customs duty and } \\
\text { import VAT on medical } \\
\text { and agricultural } \\
\text { equipment }\end{array}$ & $\begin{array}{l}\text { Ensuring } \\
\text { availability of } \\
\text { medicine and } \\
\text { promoting } \\
\text { agricultural } \\
\text { development }\end{array}$ & $\begin{array}{l}\text { VAT Act } \\
\text { SI17 of } 1999 \\
\text { SI13 of } 2003\end{array}$ & n.a. & Medical/agricultural Equipment \\
\hline
\end{tabular}

* Sunset provision 31/12/2016

Source: Customs and Excise Act, Customs and Excise Regulations, various SIs 


\subsubsection{Corporate income tax}

The income tax framework in Zambia includes various tax expenditure provisions such as: non-taxation of capital gains; loss carry-forward; capital allowances; tax holidays; multiple tax rates across sectors; and non-taxation of certain types of personal emoluments. However, as explained earlier, the analysis of tax expenditures below is limited to corporate income taxation, specifically the multiple corporate income tax rates, extended loss carry-forward and accelerated depreciation allowances.

Table 5 presents the details of tax expenditure provisions related to the corporate income tax rate - categories of income subject to a tax rate lower than 35 per cent or 15 per cent for dividend and interest income. A total of fourteen income tax reductions/exemptions were identified in the legislation, with tax rates ranging from 0 per cent to 33 per cent. ${ }^{11}$

\section{Table 5 Corporate income tax rates, tax expenditures in Zambia, 2016}

\begin{tabular}{|c|c|c|c|c|}
\hline Category of Income Stream & $\begin{array}{l}\text { Income } \\
\text { Tax } \\
\text { Rate \% }\end{array}$ & $\begin{array}{l}\text { Legislation } \\
\text { (The Income Tax Act, } \\
\text { Volume 18, Chapter } 323 \text {, } \\
\text { Laws of Zambia) }\end{array}$ & $\begin{array}{l}\text { Sunset } \\
\text { provision }\end{array}$ & Policy Objective \\
\hline Mining Operations & $30 \%$ & $\begin{array}{l}\text { Charging Schedule, } \\
\text { Part II, Paragraph } 3\end{array}$ & No & $\begin{array}{l}\text { Supporting mining operations } \\
\text { during periods of low } \\
\text { commodity prices }\end{array}$ \\
\hline $\begin{array}{l}\text { Public Benefit Organisations (On } \\
\text { income from business) }\end{array}$ & $15 \%$ & $\begin{array}{l}\text { Charging Schedule, } \\
\text { Part II, Paragraph } 5\end{array}$ & No & $\begin{array}{l}\text { Supporting organisations in } \\
\text { providing services of benefit to } \\
\text { society }\end{array}$ \\
\hline Farming & $10 \%$ & $\begin{array}{l}\text { Charging Schedule, } \\
\text { Part II, Paragraph } 5\end{array}$ & No & $\begin{array}{l}\text { Securing food production and } \\
\text { reducing rural poverty rates }\end{array}$ \\
\hline Agro-processing & $10 \%$ & $\begin{array}{l}\text { Charging Schedule, } \\
\text { Part II, Paragraph } 5\end{array}$ & No & Encouraging diversification \\
\hline $\begin{array}{l}\text { Non-traditional exports } \\
\text { - Including foreign earnings by Sun } \\
\text { International Limited }\end{array}$ & $15 \%$ & $\begin{array}{l}\text { Charging Schedule, } \\
\text { Part II, Paragraph } 5\end{array}$ & No & $\begin{array}{l}\text { Encouraging the diversification } \\
\text { of the economy }\end{array}$ \\
\hline $\begin{array}{l}\text { Chemical manufacture of fertilizer (and } \\
\text { manufacture of organic fertilizer) }\end{array}$ & $15 \%$ & $\begin{array}{l}\text { Charging Schedule, } \\
\text { Part II, Paragraph } 5\end{array}$ & No & $\begin{array}{l}\text { Supporting the local fertilizer } \\
\text { manufacturing industry }\end{array}$ \\
\hline Rural enterprise for first five years* & $30 \%$ & $\begin{array}{l}\text { Charging Schedule, } \\
\text { Part II, Paragraph } 5\end{array}$ & No & Promoting rural development \\
\hline $\begin{array}{l}\text { Lusaka Stock Exchange listed } \\
\text { companies in the first year of listing }\end{array}$ & $33 \%$ & $\begin{array}{l}\text { Charging Schedule, } \\
\text { Part II, Paragraph } 3\end{array}$ & No & $\begin{array}{l}\text { Encouraging companies to list } \\
\text { on the Lusaka stock exchange }\end{array}$ \\
\hline $\begin{array}{l}\text { Lusaka Stock Exchange listed } \\
\text { companies if residents hold } 33 \% \text { of } \\
\text { issued stock in the first year of listing, - } \\
5 \%\end{array}$ & $30 \%$ & $\begin{array}{l}\text { Charging Schedule, } \\
\text { Part II, Paragraph } 3\end{array}$ & No & $\begin{array}{l}\text { Encouraging domestic } \\
\text { companies to list on the } \\
\text { Lusaka stock exchange }\end{array}$ \\
\hline \multicolumn{5}{|c|}{$\begin{array}{l}\text { Business Enterprise Approved by ZDA and carrying on manufacturing activities in a rural area, a multifacility economic } \\
\text { zone or industrial park }\end{array}$} \\
\hline $\begin{array}{l}\text { Rate reduced to } 0 \% \text { on income earned } \\
\text { in year } 0-5 \text {, from the first year profits } \\
\text { are returned }\end{array}$ & $0 \%$ & $\begin{array}{l}\text { Charging Schedule, } \\
\text { Part II, Paragraph } 5\end{array}$ & No & $\begin{array}{l}\text { Promoting investment in rural } \\
\text { areas, MFEZs and industrial } \\
\text { parks }\end{array}$ \\
\hline \multicolumn{5}{|c|}{ Dividend Income (Benchmark rate is $15 \%$ ) } \\
\hline $\begin{array}{l}\text { Dividend declared from farming } \\
\text { income, for the first } 5 \text { years from } \\
\text { commencing farming operations }\end{array}$ & $0 \%$ & $\begin{array}{l}\text { Second Schedule, } \\
\text { Part IV, Paragraph } 7\end{array}$ & & Securing food production \\
\hline $\begin{array}{l}\text { Dividends declared by mining } \\
\text { companies }\end{array}$ & $0 \%$ & $\begin{array}{l}\text { Second Schedule, } \\
\text { Part IV, Paragraph } 6\end{array}$ & & \\
\hline
\end{tabular}

The ZDA Act also provides for negotiation of additional fiscal incentives granted through an Investment Protection and Promotion Agreement (IPPA) to an investor that invests more than US\$10 million in a priority sector. These agreements are not included in the overview above. 
Dividends declared by companies approved by ZDA. For 5 years from the year of commencement of operations**

Other (Benchmark rate is $35 \%$ )
0\% Charging Schedule, No Part II, Paragraph 5
Promoting investment in priority sectors, MFEZs and industrial parks

\begin{tabular}{llll}
\hline Rental Income & $10 \%$ & Charging Schedule, & No \\
& Part II, Paragraph 5
\end{tabular}

\footnotetext{
* Rural areas are defined as any areas that have not been defined as a municipality or city

** Companies engaged in the assembly of motor vehicles, motor cycles and bicycles, operating in a rural area, MFEZ or industrial park

Source: Income Tax Act, Volume 19, Chapter 323, Laws of Zambia; Micro, Small and Medium Enterprise Development Policy, Ministry of Commerce, Trade and Industry, 2008
}

The tax expenditures identified consist of general tax expenditure provisions and specific investment incentives derived from the ZDA Act relating to specific priority sectors and multifacility economic zones (MFEZs).

Beyond corporate income tax rates, the Zambian tax system also provides for a number of tax expenditures on income tax through loss carry-forward, as outlined in Table 6. Normally losses can be carried forward for a period of five years after the year in which the loss was incurred. However, the Income Tax Act allows businesses involved in mining operations and electricity generation to carry forward losses for a period of ten years.

Table 6 Loss carry-forward, tax expenditures in Zambia, 2016

\begin{tabular}{|c|c|c|c|c|}
\hline Category of income stream & $\begin{array}{l}\text { Number } \\
\text { of } \\
\text { years }\end{array}$ & $\begin{array}{l}\text { Legislation } \\
\text { (The Income Tax Act, } \\
\text { Volume } 18, \text { Chapter } 323, \\
\text { Laws of Zambia) }\end{array}$ & $\begin{array}{l}\text { Sunset } \\
\text { provision }\end{array}$ & Policy objective \\
\hline $\begin{array}{l}\text { Mining operations (limited to } 50 \% \text { of } \\
\text { annual tax liability) }\end{array}$ & $\begin{array}{l}10 \\
\text { years }\end{array}$ & $\begin{array}{l}\text { Charging Schedule, } \\
\text { Part IV, Paragraph } 30, \\
\text { Subsection } 2 \text { (i) }\end{array}$ & No & Promoting investment in mining \\
\hline Electricity generation & $\begin{array}{l}10 \\
\text { years }\end{array}$ & $\begin{array}{l}\text { Charging Schedule, } \\
\text { Part IV, Paragraph } 30 \text {, } \\
\text { Subsection } 2 \text { (ii) }\end{array}$ & No & $\begin{array}{l}\text { Supporting investment in electricity } \\
\text { generation }\end{array}$ \\
\hline
\end{tabular}

Source: Income Tax Act, Volume 19, Chapter 323, Laws of Zambia

The tax expenditure provisions related to corporate capital depreciation are grouped according to the main asset categories with generally applicable annual capital allowance rates (as explained in Box 2). Table 7 illustrates the generally applicable annual rate defined as the benchmark tax under each asset category, along with the specific tax expenditure provisions that diverge from this general rate.

We find that provisions for tax expenditures related to capital allowances benefit mainly priority sectors, MFEZs, industrial parks, mining, mineral processing, manufacturing, electricity generation, tourism, farming and agro-processing.

Capital allowances for mining companies in particular have been the subject of much debate in Zambia. Generally, due to the capital-intensive nature of mining operations, many countries allow accelerated depreciation of capital for mining operations. In recent years Zambia has limited the scope for accelerated depreciation of mining assets. Currently, mining operations are accessing accelerated depreciation on industrial and commercial buildings and more-mining specific infrastructure investment. Notably, however, the annual rates for machinery and plant for mining are the same as the generally applicable rates for this asset category. 
Table 7 Corporate capital allowances, tax expenditures in Zambia, 2016

Category of capital expenditure
Rate

Legislation

Volume 18, Chapter 323

Laws of Zambia)
Sunset Policy

provision objective

Industrial buildings

\section{Benchmark}

Investment allowance (manufacturing only and in charge year)

Initial allowance (In charge year)

Annual wear and tear allowance

(10\% in case of low cost housing)

\section{Tax expenditure provisions}

Improvement allowance - priority sector MFEZ or industrial park (in charge year)

Mining operations

Commercial buildings
10\% Part IV, Paragraph 34

$10 \% \quad$ Fifth Schedule,

Part I, Paragraph 3

5\% Fifth Schedule,

Part I, Paragraph 4

100\% Fifth Schedule, No

Part I, Paragraph 4A

No

Promoting investments in priority sectors, MFEZs and industrial parks.

\section{Benchmark}

Annual wear and tear allowance

2\% Fifth Schedule,

Part IV, Paragraph 22

Subsection (1)

\section{Tax expenditure provisions}

Improvement allowance - priority sector MFEZ or industrial park (in charge year)

\begin{tabular}{|c|c|c|c|}
\hline $100 \%$ & $\begin{array}{l}\text { Fifth Schedule, } \\
\text { Part I, Paragraph 4A }\end{array}$ & No & $\begin{array}{l}\text { Promoting investments in } \\
\text { priority sectors, MFEZs } \\
\text { and industrial parks. }\end{array}$ \\
\hline
\end{tabular}

Mining operations

$25 \%$

Fifth Schedule,

No

Part IV, Paragraph 22 ,

Subsection (1)

Implements, machinery or plant

\section{Benchmark}

Annual wear and tear allowance

Mining operations

$25 \%$

$50 \%$

Annual wear and tear allowance (electricity generation, farming, mineral processing, agro-processing, manufacturing, tourism and leasing)

Vehicles

25\% Fifth Schedule,

Part II, Paragraph 10,

Subsection 3; Fifth

Schedule, Part V

Fifth Schedule,

Part IV, Paragraph 22

Subsection (1)

Fifth Schedule,

Part II, Paragraph 10,

Subsection 5
No

Promoting investments in priority sectors, MFEZs and industrial parks.

\section{Benchmark}

Commercial

Non-commercial

$25 \%$

$20 \%$
Fifth Schedule,

Part V

Fifth Schedule, Part V 


\section{Benchmark}

Premium allowance on straight line basis deduction equal to the amount of the

premium or the like, divided by the period for

which the right is granted.

Tax expenditure provisions

Mining operations
Fifth Schedule,

Part III

25\% Fifth Schedule

Part IV, Paragraph 22,

Subsection (1)

OTHER CAPITAL ALLOWANCES IN BENCHMARK TAX SYSTEM

\begin{tabular}{llll} 
Mining, other & & \\
\hline Mining specific infrastructure \& expenses & $25 \%$ & Fifth Schedule, & No \\
prior to commencement of operations & & $\begin{array}{l}\text { Part IV, Paragraph 22, } \\
\text { Subsection (1) }\end{array}$ & Promoting investment in \\
\end{tabular}

Farming, other

\begin{tabular}{|c|c|c|c|c|}
\hline $\begin{array}{l}\text { Farm improvement allowance on fencing, } \\
\text { brick or stone wall and an allowance of } \\
\text { ZMW10 million for dwellings occupied by } \\
\text { farm workers, in the particular year. }\end{array}$ & $100 \%$ & $\begin{array}{l}\text { Sixth Schedule, } \\
\text { Part I, Paragraph } 2\end{array}$ & No & $\begin{array}{l}\text { Promoting investment in } \\
\text { farming. }\end{array}$ \\
\hline $\begin{array}{l}\text { Farm works allowance for the full cost of } \\
\text { stumping and clearing, works for prevention } \\
\text { of soil erosion, boreholes, wells, aerial and } \\
\text { geophysical surveys and water conservation. }\end{array}$ & $100 \%$ & $\begin{array}{l}\text { Sixth Schedule, } \\
\text { Part II, Paragraph } 5\end{array}$ & No & $\begin{array}{l}\text { Promoting investment in } \\
\text { farming. }\end{array}$ \\
\hline $\begin{array}{l}\text { Development allowance for any person who } \\
\text { incurs capital expenditure on the growing of } \\
\text { tea, coffee or banana plants or citrus trees or } \\
\text { similar plants or trees (in the charge year) }\end{array}$ & $10 \%$ & Part IV, Paragraph 34 & No & $\begin{array}{l}\text { Promoting investment in } \\
\text { farming. }\end{array}$ \\
\hline
\end{tabular}

\section{Tax expenditure evaluation}

Section 4 scrutinises the legal framework of the provisions in the tax expenditure evaluation framework outlined in Box 1. The analysis is exclusively focused on the relevance of the tax expenditure provisions, since estimating the implications of the tax expenditure provisions on revenue is beyond the scope of this paper. The aim is to identify general questions and risks associated with tax expenditure provisions in Zambia.

First, the general characteristics of the tax expenditure provisions are discussed and potential gaps in design are identified. Discussion in this section is structured around the four main topics derived from tax evaluation questions in Box 1:

- Prevalence of discretionary measures in implementing tax expenditures

- Lack of sunset provisions for tax expenditure provisions

- Lack of a clear policy rationale for tax expenditures

- Administrative burden associated with the design of tax expenditure provisions.

This is followed by a more specific discussion of ZDA investment incentives, which include both income and customs tax provisions. The discussion in this part is focused on four main themes:

- Ambiguity and frequent changes in legal framework for tax expenditures

- Alignment of tax expenditure policy objectives to general policy framework 
- Suitability of tax expenditure design for promoting compliance

- Coordination and enforcement capacity across government agencies that administer tax expenditures.

\subsection{General characteristics of tax expenditures}

\subsubsection{Prevalence of discretionary measures}

The legal framework of the Zambian tax system complicates the task of compiling an inventory of tax expenditures. Many exemptions are granted through discretionary powers; these exemptions are not included in the Acts or any other documents that require parliamentary approval.

Furthermore, lack of transparency in the legal framework has the potential to complicate tax administration. For example, for customs tax expenditures granted by the minister of finance, the ZRA requires taxpayers to submit a copy of the SI granting the exemption as part of the customs procedure. It could be argued that this creates opportunities for subjective interpretation of tax legislation by customs officers, and uncertainty in the understanding of tax legislation among taxpayers.

\subsubsection{Lack of sunset provisions}

Most tax expenditure provisions do not include sunset provisions to set a specific time limit for the provisions, or allow for evaluation against specific policy objectives.

For tax expenditures aimed at investment promotion (ZDA, MFEZs) and specific sectors (for instance aviation and electronic communication), sunset provisions provide an incentive to improve productivity in order to be able to operate without government support. To a certain extent this also discourages rent-seeking behaviour, and weeds out the less successful businesses. These objectives are partially met through time limits on access for specific companies that apply under certain tax expenditure provisions, but they do not create any impetus to evaluate the tax provision as a whole.

Sunset provisions also have an important function for tax expenditures with policy objectives that go beyond investment promotion, as they create an opportunity to evaluate performance compared to other policy tools (such as direct expenditures).

The lack of pre-set expiration dates for tax expenditures means that the potential cost of ineffective and inefficient tax expenditures in terms of lost revenue are higher, as revenue loss can accumulate over years before tax provisions are amended.

\subsubsection{Lack of a clear policy rationale}

The most common justifications for granting tax expenditures in Zambia include:

- Promoting local and foreign investments

- Supporting certain sectors of the economy

- Supporting organisations perceived to provide goods and services of benefit to society

- Easing the administrative burden for certain government activities.

However, a number of tax expenditure categories seem to have no clear policy rationale. This includes: tax exemptions on sporting equipment, aircraft stores and equipment, and public transport aircraft. These exemptions mostly benefit corporations and wealthy individuals, and it is difficult identify any broad benefit to society. 
The policy rationale for other tax provisions is more debatable. Three types of tax expenditures are discussed in greater detail below:

First, exemptions on goods for the president of the Republic of Zambia, national assembly, armed forces and government in general can be perceived as elite benefits, and are not based on any economic argument. Moreover, these provisions tend to complicate the tax administration system and create opportunities for abuse. For instance, Fjeldstad and Heggstad (2011) argue that this type of exemption provides an incentive to leak surplus imports into the domestic market. On the other hand, one could argue that they serve to ease the administrative burden on government as a whole. Repealing these tax exemptions would presumably require an equivalent increase in funding for government institutions.

Determining the net benefit of these tax provisions would require more in-depth analysis of their use.

Second, while exemptions to certain government programmes, such as infrastructure and utility projects, can be justified for various policy, administrative and social reasons, the same argument is less convincing for exemptions for donor agencies, companies engaged in development programmes and public benefit organisations. Indeed, these provisions serve to increase the administrative cost and create distortions, inefficiencies and opportunities for various forms of abuse. ${ }^{12}$ These include:

- Leakage of surplus imports to the domestic market

- Promoting more capital-intensive imported technologies as opposed to labour-intensive modes of operation

- Giving an advantage to companies that import most of their inputs over locally-sourced (and -taxed) companies.

Lastly, a number of tax expenditure provisions are aimed at supporting specific sectors of the economy, including exemptions for electronic communications, aviation, energy-saving equipment, mining, farming, chemical manufacture of fertiliser, and enterprises operating in MFEZs. While there may be a legitimate policy argument for some of these exemptions, especially in the short term, the scope of these exemptions is very broad and thus significantly erodes the tax base. It is also important to consider the risk of poorly-designed policies in the long term - tax exemptions can be politically difficult to repeal, and may lead to unintended consequences. For instance, exemptions on customs tax may serve to discourage the development of a domestic sector in specific goods and services. This applies to ZDA incentives in particular; these are discussed in greater detail in the following section.

\subsubsection{Heavy administrative burden on the tax authority}

The design of tax expenditure provisions in Zambia needs continuous monitoring and evaluation to avoid fraud and ensure policy objectives are meeting stated policy objectives. This includes ensuring compliance with tax expenditure conditions, regulating incentivised parties and conducting cost-benefit analysis.

For instance, the multiple corporate income tax rates create an opportunity for tax avoidance through tax planning. One company may engage in several business activities across different sectors with varying tax provisions, which may include tax incentives. This creates an opportunity to shift profits towards activities with relatively lower effective tax rates through tax planning. A company may set up operations in a new sector altogether to take advantage

Many donor organisations around the world support a policy shift in relation to tax expenditures. Fjeldstad and Rakner (2003) document how Senegal and Togo implemented policy reforms to eliminate tax exemptions related to foreign assistance by fully taxing imports and subsequently refunding tax paid to the relevant agencies. 
of this opportunity. These provisions place a significant burden on the capacity-constrained tax administration to ensure compliance. It may therefore be preferable to replace the multiple tax rate structure with a single universal corporate income tax rate, which could create fiscal space to lower the standard rate (IMF 2012).

Capital allowances are also a prominent feature of tax expenditure provisions under corporate income tax. The impact of capital allowances on firms depends to a great extent on design. Nevertheless, it can generally be said that capital allowances have little value for firms that are unprofitable in the initial years. This type of provision generally favours investments by firms that are already operational. Another important characteristic of capital allowances is that their value depends on the size of the investment: since capital-intensive methods require relatively larger investments, capital allowances tend to favour this type of production rather than labour-intensive production. While this type of tax provision is usually easy to administer, there is a risk of abuse from firms engaging in sham sale and repurchase of assets (Nathan-MSI Group 2004).

As discussed in the next section, implementing a rigorous monitoring and evaluation system for tax expenditures would require significant additional administrative capacity within government, and much better coordination between the government agencies involved (ZRA, MoF, ZDA, MCTI, etc). However, even if the capacity constraints could be overcome there may still be serious political obstacles associated with repealing and adjusting tax expenditures. The beneficiaries of tax expenditures are often few and coordinated, and able to lobby policymakers. It is therefore preferable to incorporate better checks and balances in the tax legislation itself. As mentioned above, this can be achieved by including sunset provisions, tying incentives to more specific policy objectives, and creating incentives for automatic compliance.

\subsection{ZDA tax incentives}

The ZDA has introduced a range of tax incentives to specific taxpayer and investor classes across both customs and domestic taxes, as listed earlier. These tax expenditures are repeated in Table 8 to allow for a more comprehensive analysis. ${ }^{13}$

Table 8 lists ZDA tax incentives provided for different taxpayer categories, including investors, enterprises in priority sectors, rural enterprises and enterprises engaged in the manufacturing of roofing sheets, and motor vehicles.

A company must submit a business plan for approval by the ZDA to qualify for the tax incentives, and indicate the extent to which the proposed investment will lead to employment, technology transfer and/or exports. It will subsequently be issued with an investment licence, or registered as a micro- or small enterprise or rural business enterprise (MoFNP 2014b). 


\begin{tabular}{|c|c|c|}
\hline & Customs taxes* & Income tax \\
\hline $\begin{array}{l}\text { Investors who invest a minimum of } \\
\$ 500,000 \text { in a priority sector, MFEZ } \\
\text { or industrial park and meet certain } \\
\text { targets in terms of employment }\end{array}$ & $\begin{array}{l}\text { Exemption from customs duty on } \\
\text { certain categories of goods for a period } \\
\text { of } 5 \text { years conditional on targets for } \\
\text { employment creation } \\
\text { Exemption from customs duty on } \\
\text { imports of machinery and equipment } \\
\text { other than spare parts required for the } \\
\text { establishment, rehabilitation or } \\
\text { expansion a business enterprise } \\
\text { operating in an industrial park or a } \\
\text { MFEZ (7 approved organisations) } \\
\text { Exemptions from customs duty payable } \\
\text { on machinery and equipment other } \\
\text { than spares for use in priority sectors } \\
\text { (271 approved organisations) }\end{array}$ & \\
\hline $\begin{array}{l}\text { Business enterprises approved by } \\
\text { ZDA and carrying on manufacturing } \\
\text { activities in a rural area MFEZ or } \\
\text { industrial park }\end{array}$ & & $\begin{array}{l}\text { Rate reduced to } 0 \% \text { for the first } 5 \text { years } \\
\text { from the commencement of operations } \\
0 \% \text { tax on payment of dividends } \\
\text { Accelerated depreciation on } \\
\text { industrial/commercial buildings and } \\
\text { implements/machinery. }\end{array}$ \\
\hline Rural enterprises $^{\star \star}$ & $\begin{array}{l}\text { Exemptions from customs duty on } \\
\text { machinery and equipment other than } \\
\text { spares }\end{array}$ & $\begin{array}{l}\text { Tax chargeable reduced by } 1 / 7 \text { for a } \\
\text { period of } 5 \text { years }\end{array}$ \\
\hline $\begin{array}{l}\text { Assembly of motor vehicles, trailers, } \\
\text { motor cycles and bicycles }\end{array}$ & $\begin{array}{l}\text { Exemptions from customs duty payable } \\
\text { on goods imported ( } 4 \text { approved } \\
\text { organisations) }\end{array}$ & $\begin{array}{l}0 \% \text { withholding tax on payment of } \\
\text { dividends }\end{array}$ \\
\hline Manufacture of roofing sheets & $\begin{array}{l}\text { Exemptions from customs duty payable } \\
\text { on goods imported ( } 3 \text { approved } \\
\text { organisations) }\end{array}$ & \\
\hline \multicolumn{3}{|c|}{$\begin{array}{l}\text { Source: Customs and Excise Regulations and Income Tax Act, Volume 19, Chapter 323, Laws of Zambia } \\
\text { * Generally, the customs tax incentives are valid for a period of } 5 \text { years from issuance of the investment licence, although } \\
\text { this is not clearly specified under all tax expenditure provisions under the Customs and Excise Regulations. } \\
\text { ** According to the ZDA Act in 2016, rural enterprises are defined as a business enterprise located in a rural area and } \\
\text { defined as any area not declared a city or municipality. }\end{array}$} \\
\hline
\end{tabular}

\subsubsection{Ambiguity and frequent changes in legal framework}

The most noteworthy exemptions in the ZDA Act are provided to investors who invest a minimum of $\$ 500,000$ in a priority sector. The general priority sectors under the ZDA Act of 2016 are listed in Box 3.

The definition of enterprises that are eligible for an income tax holiday differs between the Income Tax Act and the ZDA Act. The ZDA Act provides for a much broader definition, with income tax holidays granted to investors who invest a minimum of $\$ 500,000$ in a priority sector, MFEZ or industrial park. Here, we adopt the definition from the Income Tax Act, which limits the income tax holiday to ZDA-licenced manufacturing enterprises in MFEZs, industrial parks and rural areas. This narrower definition has not been incorporated into the Customs and Excise Act, which includes tax expenditure provisions for rural business enterprises and priority sectors. 


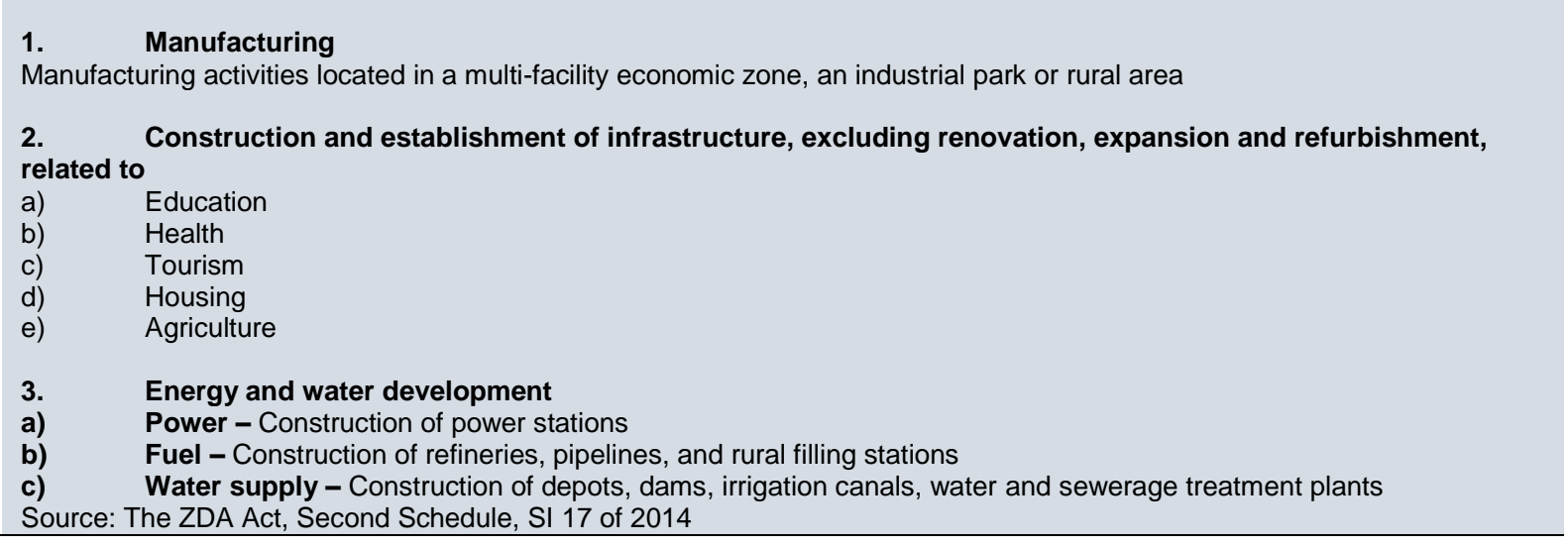

It is important to note that the definition of ZDA priority sectors changed many times in the past decade before arriving at the current, much narrower definition. ZDA incentives in general have been characterised by frequent changes coupled with grandfathering provisions - implying that some companies continue to benefit from tax incentives that were in place at the time they were issued with investment licences. The ZRA Practice Notes 2016 indicate that enterprises with ZDA investment licences issued prior to October 2013 continue to benefit from income tax holidays under the old legal framework, which provided full or partial income tax holidays for a period of up to ten years.

This again illustrates the potential risks associated with tax expenditures - they can continue to undermine revenue collection several years after provisions have been removed from the legal framework.

\subsubsection{Alignment to general policy framework}

An important aspect of analysing tax expenditures is ensuring that the tax provisions are aligned to other government policies. Generally, public policy in Zambia is guided by the fiveyear national plan. The Revised Sixth National Development Plan (RSNPD) 2013-2016, in place in 2016, identifies the following six priority growth sectors: agriculture, livestock and fisheries; mining; tourism; manufacturing; and construction and energy (MoFNP 2014a). The most recent ZDA priority sectors have a particular focus on construction, but otherwise they are fairly well-aligned to the growth sectors of the RSNDP.

As mentioned above, there is some inconsistency in the definition of businesses that qualify for investment incentives across the ZDA and Customs and Excise Acts on the one hand, and the Income Tax Act on the other.

\subsubsection{Promoting compliance requires better design of tax expenditures}

ZDA incentives are for the most part formulated as tax holidays - reduced corporate income tax rates for a certain number of years. It could be argued that tax holidays mostly benefit short-term investors, who are looking to make quick gains and do not plan to operate in the long term. A tax holiday represents a small gain compared to the long-term income tax system for long-term investors.

A counter-argument would be that companies require a period of learning-by-doing before becoming competitive in the national/international market. In this case a tax holiday could be interpreted as the government assuming some of the initial risk to the operation. However, this policy would only be effective if coupled with effective monitoring and evaluation to weed 
out the less successful firms.

More generally, exemptions and income tax holidays can be ineffective policy tools as they do not create direct incentives for compliance with policy objectives, and require systematic monitoring. There are more efficient alternatives. For instance, a more effective tax provision for employment creation is to grant tax credits for each employee. This policy reduces the need for monitoring - companies have an incentive to create more employment in order to access tax credits - and could reduce the overall cost in terms of revenue forgone per employee.

\subsubsection{Lack of coordination and enforcement capacity across government agencies}

Both the ZDA Act (Section 77) and Customs Regulations (Regulation 98B) include provisions that allow the authorities to suspend benefits conferred through the incentives if the investment is not being implemented according to plan. However, the law only allows for suspension of benefits from the point of suspension of the licence, and there is no claw-back provision for benefits conferred up to that point.

Moreover, there is some doubt about the extent to which investment pledges are binding and the contractual obligations associated with an investment licence. MoFNP (2014b) finds that most holders of investment licences surveyed indicated that they had made no investment pledges.

Beyond contractual obligations, efficient tax expenditure policies also require enforcement capacity and coordination on the part of the ZDA and government agencies involved.

ZDA views its role as investment facilitation rather than enforcement of investment pledges this is perceived to be the responsibility of ZRA and MoF. ZDA does maintain a database of investment projects; this is updated through monitoring and evaluation of compliance with investment pledges (OECD 2012 and interview with ZDA employees). However, due to capacity constraints only selected investment projects are monitored, and is limited to the first year of operation (Munyadi et al. 2012 and interview with ZDA staff). Moreover, evaluation of projects is principally aimed at identifying constraints to investment and evaluating the business environment. Beyond ensuring that companies operate in the appropriate sectors and confirming the amount invested and machinery purchased, evaluations are not aimed at regulating investment pledges (interviews with ZDA staff).

Coordination across different government agencies also seems to be lacking. The ZDA is permitted by law to revoke investment licences in cases where the terms and conditions of the licences have been breached (ZDA Act, Section 75), or in cases where specific goals in terms of employment creation and training have not been met (ZDA Act, Section 69). However, this differs from the provisions under Customs Tax Regulations, where the responsibility for revoking incentives related to employment creation is vested with the minister of finance (Regulation 98B (2)).

In practice, the degree of control and process may differ across tax incentive categories. In order to access customs tax exemptions on imports of capital goods, the qualifying company must undergo an elaborate process of control involving ZDA, MoF and ZRA, requiring proof of implementation of investment pledges before approval of tax exemptions (OECD 2012 and interview with ZDA officers). Conversely, the responsibilities and process of granting and administer incentives under income tax are more unclear. Investors who are granted a licence by ZDA do not always seek formal approval of income tax incentives from ZRA, meaning that the ZRA would be unaware of erosion of the tax base (ZRA data and interviews with ZRA officers). 
Overall, the analysis suggests that there is scope to review the tax incentives provided under the ZDA Act to ensure: better alignment with the general policy framework; tax provisions are more effective in meeting stated policy objectives; tax policy is adapted to capacity constraints of relevant government agencies; and better inter-institutional coordination.

\section{Reporting and evaluation of tax expenditure in Zambia}

The above analysis has identified a number of risks associated with tax expenditure provisions in Zambia, and makes a case for an improved reporting and evaluation system.

Global best practice discussed previously provides some guidance, but a monitoring and evaluation system needs to be adapted to existing institutional capacity in Zambia. The institutional capacity to implement each of the three steps associated with establishing an evaluation framework for managing tax expenditures (Section 2.6.1) is considered in turn.

The definition of a benchmark tax system and identification of tax expenditures is a relatively simple process for the tax authority and can be continuously revised. This process would also benefit from a more general improvement in the transparency of tax legislation, which can be achieved through reducing the use of discretionary measures and consolidating tax legislation and regulation into specific legal documents.

The second step involves estimating the impact of tax expenditures on revenue. If the revenue forgone method is adopted to estimate impact on revenue, the estimation is relatively straightforward, and largely dependent on the tax administration and data management system used by the tax authority. Currently, ZRA has relatively advanced tax administration systems - ASYCUDA World for customs taxes, and TaxOnline for domestic taxes. Both of these allow for online filing of tax-related documents and payment of taxes. The computation of revenue forgone is already done for customs taxes in ASYCUDA World, and a similar system could be implemented for domestic taxes through TaxOnline. After initial calibration of the system the process would be done automatically, and thus would not impose a significant additional burden on the tax authority.

\section{Box 4 Estimates of revenue impact in Zambia}

As previously mentioned, only partial estimates of the impact on revenue of tax expenditure provisions in Zambia have been made in the past. Nevertheless, these estimates may help shed light on the importance of the issue, and a brief overview of the existing estimates is provided below:

- JCTR (2011) estimate revenue forgone due to customs tax expenditures alone at ZMW1,493 billion (not rebased) or equivalent to $1.9 \%$ of GDP in 2009 . With $25 \%$ attributable to COMESA and SADC trade protocols.

- IMF (2012) estimate the total revenue forgone from all taxes except personal and corporate income tax at ZMW589 billion in 2010, ZMW1191 billion in 2011, ZMW1502 billion in 2012 . This is equivalent to $0.8 \%$ of GDP in $2010,1.3 \%$ of GDP in 2011 and $1.4 \%$ of GDP in 2012.

- Sladoje (2015) estimates the total revenue forgone due to customs and corporate income tax expenditure provisions at ZMW5 billion or 3.5\% of GDP in 2013. The estimate includes customs tax, excise duty, import VAT, export duty, fuel levy and tax expenditure provisions related to corporate income tax rates. The breakdown across tax expenditure categories is as follows: customs duty $-2.0 \%$, excise duty $-0.6 \%$, corporate income tax $-0.4 \%$, import VAT $-0.3 \%$, fuel levy $-0.2 \%$, export duty $-0.0 \%$.

All estimates above employ the revenue forgone method, which should be interpreted with caution due to previouslymentioned caveats (see footnote 2).

The last step in the process, subjecting tax expenditures to effective evaluation and control, is also the most difficult, and cannot be done without better integration of tax expenditures 
into the national budgeting process. Indeed, many countries struggle to establish a prudent budgetary framework for managing direct expenditures alone.

\author{
In Zambia, the process for evaluating tax expenditures and direct expenditures may be \\ constrained by institutional capacity. With these institutional constraints, the benefits of a \\ prudent budgetary framework for tax expenditures may also be limited. Therefore, the \\ recommendation of this paper is to initially adopt a simplified approach, introducing \\ budgetary ceilings on revenue forgone due to tax expenditures. More elaborate measures \\ can be considered subsequently, depending on the impact of the reform.
}

It is also important to recognise that many tax expenditure provisions serve a valid purpose. The intention should not be to rid the tax system of all tax expenditure provisions, but simply to ensure they are subject to monitoring and evaluation on par with direct expenditures.

\title{
Box 5 Monitoring and evaluation of tax expenditure - cross-country examples
}

\section{Chile}

The Chilean constitution includes a provision that requires all fiscal benefits provided through the tax system to be presented in the budget law each year. Accordingly, the Chilean tax authority estimates the revenue impact of tax expenditures on an annual basis and these are included in the Budget of Public Finances. The tax authority employs the revenue forgone method, and presents estimates for the past 3 years that are broken down across sectors, tax types and tax expenditure provisions. However, the report does not specify the policy objective of each tax expenditure provision. Also, tax expenditures are only subject to evaluation at the time the law is enacted rather than continuously. Most tax expenditure provisions also lack sunset provisions (Burton and Stewart 2011).

\section{India}

A Statement of Revenue Impact of Tax Incentives under the central tax system was first presented before the Indian Parliament in 2007, and has continued to be prepared on an annual basis. The statement includes an overview of the major tax expenditure provisions across various tax types, along with their estimated revenue impact for the year in which the budget is presented and the previous year. The estimates are reported by taxpayer and tax expenditure category. The analysis also includes an estimate of the effective tax rate for companies in various sectors. No overview is provided of the policy motivation for the various tax expenditure provisions (Union Budget of India 2016-17 - Annex 15).

\section{Mauritius}

Mauritius conducted the first estimation of the revenue impact of tax expenditures in 2005. Tax expenditure estimates were formally included in the annual budget in 2007. The tax expenditure report includes an overview of the main tax expenditure provisions across different tax types and the associated revenue forgone. Over the following years, Mauritius enacted a number of tax reforms that contributed to reducing the value of tax expenditures from 3.2\% in 2006-07 to 1.3\% in 2012. According to the director general of the Mauritian Tax Authority, the reforms allowed Mauritius to 'remove a significant number of low-income earners from the tax net and reduce the tax burden on middle-income earners' and to 'reduce administrative and compliance costs significantly'. Moreover, despite the removal of tax incentives foreign investments in Mauritius continued to grow (Africa Tax Spotlight 2012).

\section{South Africa}

As a regional leader in Southern Africa and beyond, South Africa has often been at the forefront of fiscal transparency reforms. This is also the case with tax expenditure reporting. Tax expenditures were part of the annual budget review for the first time in 2003, when the budget document included an overview of tax expenditure provisions across different tax types, but no revenue impact estimates. The revenue estimates were only included in the 2011 Budget Review. Since then the South African treasury has continued to report annually on the revenue impact of tax expenditures, including more tax expenditure provisions along with estimates of their revenue impacts.

In 2016, the tax expenditure report includes estimates of the revenue impact for the last 4 financial years. The revenue impacts are calculated using the revenue forgone method, and are reported by tax expenditure category and tax type. The report also provides the rationale for all new tax provisions introduced as part of the budget, including tax expenditure provisions, although no forecasts of revenue impacts are included.

The South African treasury conducts periodical evaluations of the impact of tax expenditure provisions. Most recently, the 2016 Medium Term Budget Policy Statement indicates that the incentive programme is being reviewed in order to 'assess performance, determine value for money, and analyse how the system as a whole supports the economy and job creation' (National Treasury Republic of South Africa Budget 2016 - Annexure C). 


\section{Summary of findings and recommendations}

Subjecting tax expenditures to more effective evaluation and controls, and integrating them into the national budgeting process, can improve the effectiveness and efficiency of government operations.

With this in mind, the purpose of this study is to contribute to the existing evidence on tax expenditures in Zambia by conducting a detailed inventory of tax expenditure provisions in the legislation, discussing their relevance and effectiveness as policy tools within the country's general policy framework, and considering how international best practice could be adapted to establish a tax expenditure reporting and evaluation system in Zambia.

Based on the analysis of legislation, twenty-one categories of tax expenditures were identified under customs taxes, fourteen under corporate income taxes, two related to extended loss-carry forward and six related to accelerated depreciation of capital.

The MoF and ZRA have in recent years successfully limited costly tax expenditure provisions relating to income tax holidays derived from ZDA investment incentives. Nonetheless, questions remain regarding the relevance, effectiveness and efficiency of tax expenditures that remain. More importantly, the country still lacks a framework to monitor and evaluate tax expenditures, and to provide clear guidance on policies relating to tax expenditures.

The paper identifies the following recommendations for consideration by policymakers:

1. Tax expenditures should be explicitly reported along with estimates of impact on revenue.

2. The relevance, effectiveness and efficiency of tax expenditure provisions as public policy tools need to be evaluated against stated policy objectives.

3. Tax expenditure reporting and evaluation should be incorporated into the national budgeting process to the extent permitted by existing institutional capacity. Initially, a simplified approach could be adopted, introducing budgetary ceilings on tax expenditures. Subsequently, depending on the impact of the reform, more targeted evaluation and control measures can be considered.

More targeted evaluation of tax expenditure provisions should be prioritised according to the estimated revenue forgone under each provision. The analysis provided in this paper has suggested a number of potential problem areas that would require further analysis. These include:

- Use of statutory instruments in implementing tax expenditure provisions.

- Lack of sunset and claw-back provisions.

- Lack of clear-cut policy objectives for tax expenditure provisions. Specifically:

- Risks associated with tax exemptions granted to elected officials, national assembly, armed forces, general government, donor agencies, companies engaged in development programmes and public benefit organisations, and whether these tax provisions should be revised.

- Efficiency and effectiveness of tax expenditures aimed at supporting specific sectors of the economy, and whether these remain relevant.

- Administrative burden and enforcement capacity of government agencies in relation to tax expenditure provisions. Specifically:

- Risks of tax avoidance due to multiple corporate income tax rates, and whether these warrant the adoption of a universal but lower standard income tax rate. 
Specifically related to ZDA investment incentives:

- Ambiguity and frequent changes in the legal framework for ZDA investment incentives. Specifically:

$\circ \quad$ Broad scope of priority sectors defined under ZDA, and whether these are aligned to general public policy goals.

- Ensuring a consistent definition of businesses that qualify for ZDA investment incentives across the Customs and Excise, ZDA and Income Tax Acts.

- Alignment of ZDA tax incentives to the general policy framework.

- Potential to adapt tax provisions to minimise the administrative burden on government agencies by using policy tools that create appropriate incentives for compliance.

- Process of granting, administering and monitoring tax incentives, and how to improve the degree of coordination across government agencies (including the roles of ZRA, ZDA, MoF and MCTI). 


\section{References}

Abbas, S., Klemm, A., Bedi, S. and Park, J. (2012) A Partial Race to the Bottom: Corporate Tax Developments in Emerging and Developing Economies, IMF Working Paper

Africa Tax Spotlight (2012) Quarterly Newsletter of the Tax Justice Network Africa, 2012, First Quarter, Volume 3

Australian Treasury (2014) Tax Expenditures Statement 2013, the Treasury, Commonwealth of Australia, Canberra: Australian Government

Balance of Payments Statistical Committee (2015) Foreign Private Investment and Investor Perceptions in Zambia 2015: Rethinking, Refocusing and Implementing Investment and Export Diversification Strategies, The Balance of Payments Statistical Committee of the Government of the Republic of Zambia

Brixi, H., Valenduc, C., Swift, Z. (eds) (2004) Tax Expenditures - Shedding Light on Government Spending through the Tax System; Lessons from Developed and Transition Economies, Washington DC: The World Bank

Burton, M. and Stewart, M. (2011) Promoting budget transparency through tax expenditure management: A Report on Country Experience for Civil Society Advocates, Tax Group. Melbourne Law School, University of Melbourne

Bwalya, S., Phiri, E. and Mpembamoto, K. (2009) How non-state actors lobby to influence budget outcomes in Zambia, Institutions and Pro Poor Growth discussion papers

CRC Sogema (2013) Tanzania PER Tax Exemption Study

Dean, S. (2012) 'The Tax Expenditure Budget is a Zombie Accountant', 46 U.C. Davis L. Rev. 265

Fjeldstad, O-H. and Rakner, L. (2003) Taxation and Reforms in Developing Countries: Illustrations for Sub-Saharan Africa, CMI Report R 6:2003, Bergen: Chr. Michelsen Institute

Fjeldstad, O-H. and Heggstad, K. (2011) The Tax Systems in Mozambique, Tanzania and Zambia; Capacity and Constraints, Chr Michelsen Institute Report

Fumpa-Makano, R. and Imakondo, M. (2015) Tax Incentives in Zambia - An Analysis of the Zambia Development Agency (ZDA), Act. Centre for Trade Policy and Development, April 2015, Lusaka

IMF (2012) Further proposals for tax base broadening, Technical Assistance Report, Zambia

IMF, OECD, UN and World Bank (2011) Supporting the Development of More Effective Tax Systems, Report to the G-20 Development Working Group

Institute of Policy Analysis and Research Rwanda (2011) East African Taxation Project:

Rwanda Country Case Study, June 2011

James, S. (2003) The Rematex Case. Background note on the SADC Tax Incentives Study, Cambridge: Kennedy School of Government 
JCTR (2011) The Taxation System in Zambia - Technical Report, January 2011

MoFNP (2014a) Revised Sixth National Development Plan 2013-2016: People Centred Economic Growth and Development, Ministry of Finance and National Planning. 2014

MoFNP (2014b) Report on the assessment of the impact of tax incentives in Zambia, Ministry of Finance and National Planning

Munyadi, K., Kosters, B and Bardadin A. (2012) Zambia Tax Incentive Study, IBFD

Nathan-MSI Group (2004) Effectiveness and Economic Impact of Tax Incentives in the SADC Region

National Treasury Republic of South Africa Budget 2016 - Annexure C, <http://www.treasury.gov.za/documents/national\%20budget/2016/review/Annexure\%20 c.pdf $>$ accessed on $6^{\text {th }}$ December

Open Budget Survey (2012) International Budget Partnership, $<$ www.internationalbudget.org $>$

OECD (2010) Tax Expenditures in OECD Countries, OECD

OECD (2012) OECD Investment Policy Review: Zambia 2012, OECD Publishing. DOI: <http://dx.doi.org/10.1787/9789264169050-en>

Phillips, L. (2012) The Globalization of Tax Expenditure Reporting: Transplanting Transparency in India and the Global South, Comparative Research in Law and Political Economy, Research Paper No 43/2012

Shaviro, D. (2004) 'Rethinking Tax Expenditures and Fiscal Language', 57 TAX. L. REV. 187,187

Sladoje, M. (2015) Tax Expenditures in Zambia 2013, Research And Planning Department, Zambia Revenue Authority (unpublished)

Swift, Z. (2006) Managing the effects of Tax Expenditures on National Budgets, World Bank Policy Research Paper 3927

TJN-Africa and ActionAid International (2012) Tax competition in East Africa: $A$ race to the bottom?, Tax Justice Network-Africa and ActionAid International

Tuomi, K. (2012) Review of Investment Incentives: Best Practice Application, F-41003-ZMB1, International Growth Centre Working Paper

Union Budget of India 2016-17 - Annex 15, <indiabudget.nic.in/ub2016-17/rec/annex15.pdf> accessed on $6^{\text {th }}$ December 


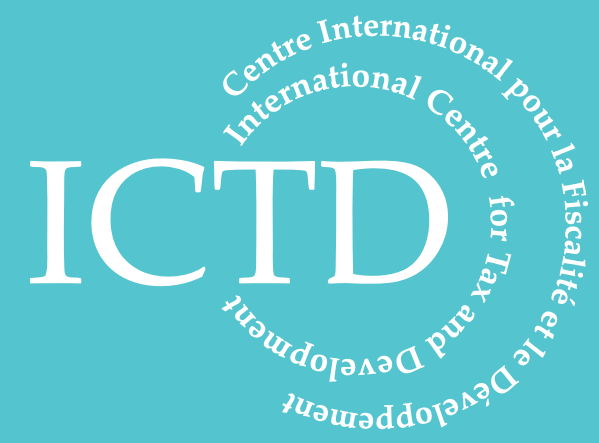

International Centre for Tax and Development at the Institute of Development Studies

Brighton BN1 9RE, UK

T: +44 (0) 1273606261

F: $+44(0) 1273621202$

E: info@ictd.ac

www.ictd.ac 